\title{
TAXPAYERS' SUITS: A SURVEY AND SUMMARY
}

\section{INTRODUCTION}

AN appeal by a Los Angeles resident challenging the constitutionality of a city ordinance conveying public land-Chavez Ravine-to the Dodgers baseball team for a new ball park was dismissed this term by the United States Supreme Court, ${ }^{1}$ but not until the litigation had caused over a year's delay in construction. ${ }^{2}$ In 1955, a Baltimorean, involing a clause in the Maryland constitution, ${ }^{3}$ successfully enjoined the mayor and other municipal officials from taking a sizeable pay increase. More recently, the Los Angeles police commissioner was prevented from buying wiretapping equipment upon proof that information obtained through the use of such equipment could not be admitted into evidence under the California constitution and, therefore, that purchases would constitute misuse of public funds. The common thread in these three diverse cases, typical of many more, is that they were "taxpayers" suits," a form of action currently available to challenge state action in at least thirty-four states, ${ }^{6}$ and municipal action in virtually every jurisdiction. ${ }^{7}$

1. Kirshbaum v. Housing Authority, 51 Cal. 2d 857, 337 P.2d 825, appcal dismisscd and cert. denied, 361 U.S. 30 (1959); see City of Los Angeles v. Superior Court, 51 Cal. 2d 423, 333 P.2d 745 (1959); Rubens v. City of Los Angeles, 51 Cal. 2d 857, 337 P.2d 825, appeal dismissed and ccrt. denied, 361 U.S. 30 (1959) (companion case to Kirshbaum); 28 U.S.L. WEEK 3067 (1958) (plaintiffs alleging violation of due process and impairment of obligation of contracts).

2. The president of the Los Angeles Dodgers said that because of delays, costs had increased by about $\$ 2,500,000$. A further $\$ 500,000$ rise in costs was anticipated. N.Y. Times, Oct. 20, 1959, p. 51, col. 4.

3. MD. CoNsr. art. $3, \S 35$.

4. Pressman v. D'Alesandro, 211 Mrd. 50, 125 A.2d 35 (1956).

5. Wirin v. Parker, 48 Cal. 2d 890, 313 P.2d 844 (1957). Contra, Black v. Impelliterri, 201 Misc. 371, 111 N.Y.S.2d 402 (Sup. Ct.), aff'd, 281 App. Div. 671, 117 N.Y.S.2d 686 (1952), aff'd, 305 N.Y. 724, 112 N.E.2d 845 (1953) ("no substantial constitutional question is presented ..."). Wirin was based on previous California criminal decisions, which unlike decisions of the New York courts, had excluded the use of evidence obtained by placing a dictograph in a house without the occupant's permission or consent. People v. Tarantino, 45 Cal. 2d 590, 290 P.2d 505 (1955); People v. Cahan, 44 Cal. 2d 434, 282 P.2d 905 (1955).

6. See notes 31-34 infra and accompanying text.

7. Alabama: New Orleans, M. \& C.R.R. v. Dunn, 51 Ala 128 (1874); Aloslia: see Valentine v. Robertson, 300 Fed. 521 (9th Cir. 1924); Arizona: Lee v. Coleman, 63 Ariz. 45, 159 P.2d 603 (1945); Arkansas: Russell v. Tate, 52 Ark. 541, 13 S.W. 130 (1890); Califormia: Santa Rosa Lighting Co. v. Woodward, 119 Cal. 30, 50 Pac. 1025 (1897) ; Colorado: Johnson-Olmsted Realty Co. v. City of Denver, 89 Colo. 250, 1 P.2d 928 (1931) ; Connecticut: Bassett v. Desmond, 140 Conn. 426, 101 A.2d 294 (1953): Delaware: Haddock v. Board of Pub. Educ., 32 Del. Ch. 245, 84 A.2d 157 (Ch. 1951); District of Columbia: Bradfield v. Roberts, 175 U.S. 291 (1899); Florida: Lanier v. Padgett, 18 Fla. 842 (1882); Georgia: Morris v. City Council, $201 \mathrm{Ga}$. 666, 10 S.E.2d 710 (1946); Idaho: Nuckols v. Lyle, 8 Idaho 589, 70 Pac. 401 (1912): Illinois: City of Springfield v. Edwards, 84 Ill. 626 (1877); Indiana: Mlitsch v. City 
The taxpayer's suit is a means of satisfying the jurisdictional requirement that plaintiffs have standing to sue. ${ }^{8}$ Normally, the "standing" doctrine, which

of Hammond, 234 Ind. 285, 125 N.E.2d 21 (1955); Iowa: Reed v. Cunningham, 126 Iowa 302, 101 N.W. 1055 (1905) (subject to requirement that taxpayer first demand of proper officers that suit be brought or show that such demand would be unavailing); Kansas: Hartzler v. City of Goodland, 97 Kan. 129, 154 Pac. 265 (1916) ; Kentucky: Howard v. Ader, $314 \mathrm{Ky} .213$, 234 S.W.2d 733 (1950) (subject to requirement that taxpayer first demand of proper officers that suit be brought or show that such demand would be unavailing); Lonisiana: Donaldson v. Police Jury, $161 \mathrm{La} .471,109$ So. 34 (1926); Maine: Allen v. Inhabitants of Jay, $60 \mathrm{Me} .124$ (1872); Maryland: Pressman v. D'Alesandro, $211 \mathrm{Md}$. 50, 125 A.2d 35 (1956) ; Massachusetts: Fluet v. Eberhardt, 294 Mass. 408, 2 N.E.2d 463 (1936); Michigan: Thomson v. City of Dearborn, 347 Mich. 365, 79 N.W.2d 841 (1956); Minmesota: Arens v. Village of Rogers, 240 Minn. 386, 61 N.W.2d 508 (1953), appeal dismissed, 347 U.S. 949 (1954); Mississippi: Mississippl Road Supply Co. v. Hester, 185 Miss. 839, 188 So. 281 (1939); Missouri: Berghorn v. Reorganized School Dist. No. 8, 364 Mo. 121, 260 S.W.2d 573 (1953); Montana: McClintock v. City of Great Falls, 53 Mont. 221, 163 Pac. 99 (1917); Nebraska: Woodruff v. Welton, 70 Neb. 665, 97 N.W. 1037 (1904); New Hampshire: Clapp v. Town of Jaffrey, 97 N.H. 456, 91 A.2d 464 (1952); New Jersey: Everson v. Board of Educ., 133 N.J.L. 350, 44 A.2d 333 (Ct. Err. \& App. 1945), aff'd, 330 U.S. 1 (1947); Nct' Mexico: Kavanaugh v. Delgado, 35 N.M. 141, 290 Pac. 798 (1930); Newe York : Aldrich v. City of New York, 208 Misc. 930, 145 N.Y.S.2d 732 (Sup. Ct. 1955); North Carolina : Rider v. Lenoir City, 236 N.C. 620, 73 S.E.2d 913 (1953); North Dakota: Weeks v. Hetland, 52 N.D. 351, 202 N.W. 807 (1925); Ohio: Pierce v. Hagans, 79 Ohio St. 9, 86 N.E. 519 (1908) ; Oklahoma: Hannan v. Board of Educ., 25 Okla. 372, 107 Pac. 646 (1909); Oregon: Carman v. Woodruff, 10 Ore. 133 (1882); Pemsylvania: Sharpless v. Mayor of Philadelphia, 21 Pa. 147 (1853) ; Rhode Island: Place v. City of Providence, 12 R.I. 1 (1878); South Carolina: Mauldin v. City Council, 33 S.C. 1 (1889); South Dakota: Weatherer v. Herron, 25 S.D. 208 (1910) (dictum); Temessee: Burns v. City of Nashville, 142 Tenn. 541, 221 S.W. 828 (1920); Texas: Cameron v. City of Waco, 8 S.W.2d 249 (Tex. Ct. Civ. App. 1928); Utah: Brummitt v. Ogden Waterworks Co., 33 Utah 285, 93 Pac. 828 (1908); Vermont: Whiting Co. v. City of Burlington, 106 Vt. 446, 175 Atl. 35 (1934); Virginia: Sauer v. Monroe, 171 Va. 421, 199 S.E. 487 (1938) (subject to requirement that taxpayer first request public authorities to suc, or show that such a request would be unavailing); Washington: Barnett v. Lincoln, 162 Wash. 613, 299 Pac. 392 (1931); West Virgitia: Chapman v. Huntington, W. Va., Housing Authority, 121 W. Va. 319, 3 S.E.2d 502 (1939); Wisconsin: Land, Log \& Lumber Co. v. McIntyre, 100 Wis. 245, 75 N.W. 964 (1898); Wyoming: Stratton v. City of Riverton, 74 Wyo. 379, 287 P.2d 627 (1955).

Research reveals no Puerto Rican or Hawaiian case allowing a taxpayer's suit on the municipal level. But since such suits have been allowed on a territorial level, see Buscaglia v. District Court, 145 F.2d 274 (1st Cir. 1944), cert. denied, 323 U.S. 793 (1945); Castel v. Atkinson, 16 Hawaii 769 (1905), it is fair to assume that these jurisdictions belong with those listed above.

Nevada's position, however, is unclear. Compare Blanding v. City of Las Vegas, 52 Nev. 52, 280 Pac. 644 (1929) (no standing-must show special injury), with Ronnow v. City of Las Vegas, 57 Nev. 332, 369, 65 P.2d 133, 147 (1937) ("while it is not necessary to decide contention that plaintiff has no legal capacity to maintain this stut is well taken, we may state that in our opinion, it is without merit").

This Comment will use the term "municipal" to include such entities as counties, cities, villages, towns, school districts, and sewer districts.

8. In Parker v. Bowron, 40 Cal. 2d 344, 254 P.2d 6 (1953), for example, a plaintiff sued on behalf of himself and as a member of a union to compel public officials to pay city 
is designed in part to ensure that cases will be decided only after they have been properly presented, ${ }^{9}$ and which is often invoked to place some check upon the assertion of judicial power over other branches of government, ${ }^{10}$ demands that plaintiff suffer specific personal injury before he is permitted to to instigate litigation. ${ }^{11}$ A would-be-plaintiff's status as a taxpayer, however,

employees a wage equal to the prevailing scale in private industry. In dismissing his complaint, the court said:

Where the complaint states a cause of action in someone, but not in the plaintiff, a general demurrer for failure to state a cause of action will be sustained . . . . [Plaintiff] alleges no facts to show that he has any rights or interest in the action .... He does not plead that he is an employee of the city, nor even that he is a resident or taxpayer of the city .... He does not claim to be a member of the interested class [city employees], and there is nothing to claim that he is "similarly situated" with those whom he pretends to represent . . . . [He] cannot give himself standing to sue by purporting to represent a class of which he is not a member.

Id. at $351-53,254$ P.2d at 9-10.

9. See Joint Anti-Fascist Refugee Comm. v. MicGrath, 341 U.S. 123, 151 (1951) (concurring opinion of Frankfurter, J.) ("Regard for the Separation of powsers ... and for the importance to correct decision of adequate presentation of issues by clashing interests ... restricts the courts of The United States to issues presented in an adversary fashion. A petitioner does not have standing to sue unless he is interested in, and affected adversely by, the decision' of which he seeks review."); cf. FREUND, O.: UnuEsSTANDING THE SupREare COURT 59 (1949) ("What he [Brandeis] discerned in declaratory judgments was a device, only somewhat less objectionable than advisory opinions, which might be used to bring before the courts questions of the validity of statutes at what he regarded as a premature stage. It was too easy by these means to expose the legislative plant to the judicial blight before it had come to full fruition."); Arnold, Trial by Combat and the Nezo Deal, 47 Harv. L. Rev. 913, 922 (1934) ("These assumptions are reconciled with practical efficiency by the notion that courts are more apt to formulate or apply rules soundly if the opposite sides are prevented from sitting around a table together in friendly conference . . . . Bitter partizanship in opposite directions is supposed to bring out the truth.").

10. See, e.g., United Pub. Workers v. Mitcheil, 330 U.S. 75, 90 (1947) ("Should the courts seek to expand their power so as to bring under their jurisdiction ill-defined controversies over constitutional issues, they would become the organ of political theorics. Such abuse of judicial power would properly meet rebuke and restriction from other branches [of government].").

11. [The court has no jurisdiction] unless the citizen shows that such conduct or threatened conduct invades or will invade a private substantive legally protected interest of the plaintiff citizen; such invaded interest must be either of a "recognized" character, at "common law" or a substantive private legally" protected interest created by statute.

Associated Indus. v. Ickes, 134 F.2d 694, 700 (2d Cir. 1943) (Frank, J.); see Mrassachusetts v. Mellon, 262 U.S. 447, 488 (1923) ("some direct injury ... not mercly that he suffers in some indefinite way in common with people generally"); ScRvirtz, THe Supreare Court 144-45 (1957) ("Unless he is adversely affected personally, as an individual, he is seeking only a judgment in the abstract upon the constitutionality of such an act. Such a proceeding ... is not enough to call for the exercise by the Court of its judicial power."); cf. Cyphers v. Allyn, 142 Conn. 699, 118 A.2d 318 (1955) (real-estate broker "cannot be harmed" by lack of clarity and precision in statute pertaining to services rendered by attorneys in real-estate matters). 
has been held sufficient to allow damage to him which is shared equally with all members of the public to form the basis of a judicially cognizable issue. ${ }^{12}$

The midnineteenth century saw the first cases in the United States which granted standing to taxpayers. A taxpayer's suit had been entertained in England as early as $1826,{ }^{13}$ but not until the Municipal Corporation's Act of $1835,{ }^{14}$ which deemed municipal officers to have a duty to treat municipal funds as a public trust, ${ }^{15}$ did English courts begin generally to allow such actions. ${ }^{10}$ Although English decisions were cited in a few early American cases, ${ }^{17}$ this country's law of taxpayers' suits developed independently. The earliest successful taxpayer's suit in the United States was apparently decided by a New York trial court in 1847,18 and, in the same year, Massachusetts enacted a statute allowing taxpayers to challenge municipal appropriations. ${ }^{19}$ Taxpayers' suits challenging municipal action were recognized in various other states during the next few decades. ${ }^{20}$ Some courts allowed their state's first taxpayer's suit

12. E.g., City of Springfield v. Edwards, 84 Ill. 626, 631 (1877) ("We may dismiss the objection that the complainant does not show in his bill that he is injured by the acts complained of, otherwise than in common with all other tax-paycrs in the city, with the observation that it has been held in this state that such an injury is sufficient to entitle him to an injunction, and that the question is not open to further discussion."). Contra, e.g., Jones v. City of Little Rock, 25 Ark. 301 (1868) (special injury needed). See generally 18 McQuilirin, Munictpal CoRporations \$ 52.14 (3d ed. 1950) [hercinafter cited as MCQuinLin].

13. Bromley v. Smith, 1 Sim. 8, 57 Eng. Rep. 482 (Ch. 1826).

14. 5 \& 6 Will. 4 , c. 76 , as amended, 45 \& 46 Vict., c. 50 (1882).

15. Attorney-General v. Aspinall, 2 My. \& Cr. 613, 623, 40 Eng. Rep. 773, 777 (Ch. 1837).

16. 4 Dillon, Municipal Corporations $\$ \$ 1574-75$ (5th ed. 1911) [hercinafter cited as Dirion].

17. See, e.g., Christopher v. The Mayor, 13 Barb. 567, 571 (N.Y. Sup. Ct. 1852) (citing Bromley v. Smith, 1 Sim. 8, 57 Eng. Rep. 482 (Ch. 1826)); Barr v. Deniston, 19 N.H. 170, 180 (1848) (citing Gray v. Chaplin, 2 Sim. \& St. 267, 57 Eng. Rep. 348 (Ch. 1825), a stockholder action, and Attorney General v. Heelis, 2 Sim. \& St. 67, 57 Eng. Rep. 270 (Ch. 1824), a suit by the Attorney General).

18. Adriance v. Mayor of New York, 1 Barb. 19 (N.Y. Sup. Ct. 1847) (citing no English precedents).

The New York Court of Appeals, emphasizing that the public prosecutor possessed sufficient power to protect the public trust and that allowance of taxpayers' actions risks flooding the courts with frivolous litigation, subsequently repudiated the idea that payment of taxes gave individuals standing to sue. Doolittle v. Supervisors of Broome County, 18 N.Y. 155 (1858); Roosevelt v. Draper, 23 N.Y. 318 (1861). This rule was in turn reversed by statute, in cases involving municipal officials. See note 26 infra and accompanying text.

19. Mass. Ann. Laws ch. $40, \S 53$ (1952). Cases subsequent to this statute have stated that passage of such an act signifies or implies that taxpayers' actions were not permitted prior to 1847 . See, e.g., Carlton v. City of Salem, 103 Mass. 141, 143 (1869) ; Prince v. Crocker, 166 Mass. 347, 358, 44 N.E. 446, 447 (1896).

20. See, e.g., Foster v. Coleman, 10 Cal. 278 (1858); City of New London v. Brainard, 22 Conn. 553 (1853); Colton v. Hanchett, 13 Ill. 615 (1852); Mayor of Baltimore v. Gill, 31 Md. 375 (1869); Barr v. Deniston, 19 N.H. 170 (1848); Sharpless v. Mayor of Philadelphia, $21 \mathrm{~Pa} .147$ (1853). 
without any authority or much rationale for accepting jurisdiction; ${ }^{21}$ another, apparently aware of the standing problem, was able to avoid it because defendants raised no objection to the court's jurisdiction. ${ }^{\text {na }}$ The courts also relied upon analogy to stockholder derivative suits in order to give standing." 3 As taxpayers' suits began to multiply, these earlier cases were cited as precedent when other jurisdictions began to hear taxpayers' actions."t

The development of taxpayer litigation since its inception reflects somewhat the panorama of American history. The early suits were all brought against municipalities and were few in number, probably because of the relatively limited municipal expenditures and activities of that era. In 1872, the machinations of "Boss" Tweed provided the impetus in New York for legislative repeal, in cases involving municipal officials, of a common-law rule against taxpayers' suits. ${ }^{25}$ With the expanding role of local government in

21. Foster v. Coleman, 10 Cal. 278, 281 (1858) ("the plaintiff is a taxpayer of the county"); Colton v. Hanchett, 13 Ill. 615 (1852) (assumed standing; apparently questioned whether bill in equity more appropriate than writ of certiorari); Merrill $v$. Plainfield, 45 N.H. 126, 134 (1863) ("any person who is a tax-payer in town and liable to be assessed for any part of such sum, may properly interfere . . . to prevent its payment and misapplication"); Sharpless v. Mayor of Philadelphia, $21 \mathrm{~Pa} .147,149$ (1853) ("it was averred in the bill that the petitioners were residents and owners of real and personal estate within the city ... and were therefore interested in a question which may increase the amount of taxes") ; Place v. City of Providence, 12 R.I. 1, 5 (1878) ("The power of ... chancery to control a municipal corporation in order to prevent ... abuse of its powers or . . . perversion of its funds is too well established to admit of any doubt, and that the application for its exercise may be made by tax-payers . . . is also well supported by authority. ... [T] he jurisdiction may be very necessary to protect the rights of a minority of tax-payers.").

22. Adriance v. Mayor of New York, 1 Barb. 19, 20 (N.Y. Sup. Ct. 1847) ("I have my doubts whether the court has jurisdiction to interfere in such a case as this. But as the defendants, by suffering the bill to be taken as confessed, have conceded the jurisdiction of the court ... I do not know that I ought to refuse the relici asked for.").

23. See, e.g., Shipley v. Smith, 45 N.M. 23, 26, 107 P.2d 1050 (1940); Sherlact: v. Village of Winnetka, 59 Ill. 389 (1871); Christopher v. Mayor of New York, 13 Barb. 567 (N.Y. Sup. Ct. 1852) ; Land, Log \& Lumber Co. v. MeIntyre, 100 Wis. 245, 75 N.W. 964 (1898). For a leading and influential exponent of this analogy see 4 DiLsus: $\S 1580$, at 2765. See generally Comment, 2 Burfaco L. Rev. 140, 145-46 (1952) ; Note, 50 HARV. L. REv. 1276 (1937).

24. See, e.g., Mrayor of Baltimore v. Gill, 31 Md. 375 (1869) (citing New York cases that were later overruled plus early Pennsylvania and Connecticut cases).

25. See An Act for the Protection of Tax-payers Against the Frauds, Embezzicments and Wrongful Acts of Public Officers and Agents, N.Y. Sess. Laws 1872, ch. 161; Ayers v. Iawrence, 59 N.Y. 192 (1874) (discussion of corruption leading to passage). See generally 4 Dirson $\$ 1578$, at 2762; Lincoln, Remedics of Tax Paycrs Against Public Officers, 33 Aldany I.J. 23 (1886); Comment, 2 Buffaro L. Rev. 140, 146-47 (1952). The present New York Statute-N.Y. Music. LAw \$ 51-is based on N.Y. Sess. Laws 1881, ch. 531, which was derived from the 1872 statute and which was amended by N.Y. Sess. Laws 1887, ch. 673, and N.Y. Sess. Laws 1892, ch. 301.

Prior to the enactment of the 1872 statute, not only were municipal taxpayers denied standing, see note 18 supra, but state prosecutors, absent statutory authorization, could 
economic activity after the Civil War, ${ }^{26}$ taxpayer litigation increased, and came to center primarily on public debt financings, letting of public contracts, and granting of public franchises and licenses. ${ }^{27}$ The larger volume of taxpayers' suits in the latter part of the century also coincided with the upsurgc in Populist-Progressive sentiment which, because of its distrust of entrenched officials and vested interests, gave rise to such other means of challenging governmental action as the initiative, referendum, and recall. ${ }^{28}$ As such litigation gained a firm basis in judicial precedent, taxpayers were allowed to challenge state as well as municipal action. ${ }^{20}$

State taxpayers have eventually been granted standing to challenge state action in most jurisdictions in which the issue has been presented, ${ }^{30}$ butt two

not recover from third parties who wrongfully appropriated municipal, as opposed to state, funds. People v. Ingersoll, 58 N.Y. 1 (1874); People v. Fields, 58 N.Y. 491 (1874).

26. See MacDonald, American City Government and Administration 67 (rev. ed. 1937) (rapid increase of city services between 1865 and 1890).

27. See, e.g., Savidge v. Village of Spring Lake, 112 Mich. 91, 70 N.W. 425 (1897) (bond issue for waterworks invalidated); Seymour v. City of Tacoma, 6 Wash. 138, 32 Pac. 1077 (1893) (bond issue for waterworks upheld); Santa Rosa Lighting Co. v. Woodward, $119 \mathrm{Cal}$. 30, 50 Pac. 1025 (1897) (enjoining officials from making contracts without sealed bids and advertising); Adams v. Brenan, 177 Ill. 194, 52 N.E. 314 (1898) (contract declared void that required employer to employ union labor only); Poppleton v. Moores, 62 Neb. 851, 88 N.W. 128 (1901), aff'd on rehearing, 67 Neb. 38s, 93 N.W. 747 (1903) (ordinance enjoined which extended length of waterworks company's exclusive franchise); Adamson v. Union Ry., 74 Hun 3, 26 N.Y. Supp. 136 (Sup. Ct. 1893) (collusive low bidder denied grant of franchise).

28. See generally, e.g., 2 Morison \& Commager, The Growtu of tue Auemean REPUBLIC 236-44, 354-84 (4th ed. rev. \& enlarged 1956).

29. See, e.g., Littler v. Jayne, 124 Ill. 123, 16 N.E. 374 (1888); Lynn v. Polk, 76 Tenn. 121 (1881).

30. Alabana: Turnipseed v. Blan, 226 Ala. 549, 148 So. 116 (1933); Alaska: sec Reynolds v. Wade, 249 F.2d 73 (9th Cir. 1957) (territorial appropriation); Ariaana: Ethington v. Wright, 66 Ariz. 382, 189 P.2d 209 (1948) ; Arkansas: Farrell v. Oliver, 146 Ark. 599, 226 S.W. 529 (1921); Colorado: Leckenby v. Post Printing \& Publishing Co., 65 Colo. 443, 176 Pac. 490 (1918); Florida: Crawford v. Gilchrist, 64 Fla. 41, 59 So. 963 (1912) (plaintiff sued as Governor, as well as taxpayer); Hawaii : sce Castle v. Atkinson, 16 Hawaii 769 (1905) (territorial expenditures); Idaho: Dunn v. Sharp, 4 Idaho 98, 35 Pac. 842 (1894); Illinois: Fergus v. Russel, 270 Ill. 304, 110 N.E. 130 (1915); Indiara: Ellingham v. Dye, 178 Ind. 336, 99 N.E. 1 (1912); Iozva: Wertz v. Shane, 216 Iowa 768,249 N.W. 661 (1933) (subject to requirement that proper statc official must first refuse to act); Louisiana: Borden v. Louisiana State Bd. of Educ., 168 La. 1006, 123 So. 655 (1929); Maryland: Christmas v. Warfield, 105 Md. 530, 66 Atl. 491 (1907); Massachusetts: Sears v. Treasurer \& Receiver Gen. 327 Mass. 310, 98 N.E.2d 621 (1951); Michigan: Carrier v. State Administrative Bd. 225 Mich. 563, 196 N.W. 184 (1923) (rehearing opinions); Minnesota: Regan v. Babcock, 188 Minn. 192, 247 N.W. 12 (1933) ; Mississippi: Chance v. Mississippi State Textbook Rating \& Purchasing Bd., 190 Miss. 453, 200 So. 706 (1941); Missouri: Castilo v. State Highway Comm'n, 312 Mo. 244, 279 S.W. 673 (1925); Montana: Hill v. Rae, 52 Mont. 378, 158 Pac. 826 (1916); Nebraska: Fischer v. Marsh, 113 Neb. 153, 202 N.W. 422 (1925); New Hampshire: Conway v. New Hampshire Water Resources Bd., 89 N.H. 346,199 Atl. 83 (1938); North Carolina: Teer v. Jordan, 232 N.C. 48, 59 S.E.2d 359 (1950); 
states-New York ${ }^{31}$ and New Mexico ${ }^{32}$-still squarely prohibit taxpayers' suits on the state level, and it is uncertain whether such suits would be entertained in fourteen other jurisdictions. ${ }^{33}$ The trend in the twentieth

North Dakota: Herr v. Rudolf, 75 N.D. 91, 25 N.W.2d 916 (1947); Ohio: Spahr v. Brown, 19 Ohio App. 107 (1925); Oklahoma: Davis v. Childers, 181 Ohla. 468 , 74 P.2d 930 (1937); Pentnsylvania: Page v. King, 285 Pa. 153, 131 Atl. 707 (1926); South Carolina: Gaston v. State Highway Dep't, 134 S.C. 402, 132 S.E. 680 (1926); South Dakota: White Eagle Oil \& Ref. Co. v. Gunderson, 48 S.D. 608, 205 N.W. 614 (1925) (allowed since Attorney General refused to prosecute suit); Tenessee: Lynn v. Poll, 76 Tenn. 121 (1881) ; Texas: Terrell v. Afiddleton, 187 S.W. 367 (Tex. Ct. Civ. App. 1916); Utals: see Lyon v. Bateman, 119 Utah 434, 441, 228 P.2d 818, 821 (1951) (dictum) ("a taxpayer should be permitted to enjoin the unlawful expenditures of tax moneys in which he has a pecuniary interest, or to prevent increased levies for illegal purposes."); Washington: State $e x$ rel. Lemon v. Langlie, 45 Wash. 2d 82, 273 P 2d 464 (1954) (allowed only after public official, upon request, refused to sue); II"isconsin: Democrat Printing Co. v. Zimmerman, 245 Wis. 406, 14 N.W.2d 428 (1944); "Wyoming: Bourne v. Cole, 53 Wyo. 31, 77 P.2d 617 (1938).

31. See, e.g., Klein v. O'Dwyer, 192 Misc 421, 80 N.Y.S.2d 343 (Sup. (t. 1948) (Board of Transportation a state agency, taxpayer cannot enjoin increase in subway fare); Bull v. Stichman, 273 App. Div. 311, 78 N.Y.S.2d 279, aff'd, 298 N.Y. 516, 80 N.E.2d 661 (1948) (taxpayer has no standing to enjoin $\$ 128,000$ state grant to Canisius College, a Roman Catholic institution); Schieffelin v. Komfort, 212 N.Y. 520, 106 N.E. 675 (1914) (special injury required before taxpayer can attack constitutionality of state acts).

32. See Asplund v. Hannett, 31 N.M. 641, 249 Pac. 1074 (1926); Shipley v. Smith, 45 N.M. 23, 107 P.2d 1050 (1940) (dictum). In Miller v. Cooper, 56 N.AI. 355, 244 P.2d 520 (1952), a taxpayer brought suit to enjoin the state and county boards of education, director of the certification department of the state board of education, a principal. three teachers, a janitor, and a minister from conducting religious practices and disseminating religious literature in a public school. Probably because state officials were joined as defendants, Davis, Standing To Challenge Goverimental Action, 39 Mrs:s. L. REv. 353, 388-89 (1955), suggests that New Afexico now gives standing to taxpayers challenging state action or, at the very least, that her law has been rendered unclear. Due to the length, reasoning, and general citation as a leading decision of the opinion in Asplund, supra, see, e.g., 58 A.L.R. 588 (1929), and the complete absence of any discussion of standing in Cooper, such a conclusion seems premature. Furthermore, the Cooper complaint was dismissed as to all of the defendants except the principal and onc of the teachers. 56 N.M. at 356, 244 P.2d at 520.

33. Uncertainty exists because:

(1) No case on the state level has been found: Connecticut; Delaware; Maine; Nevada (indeed, it is unclear whether Nevada will permit taxpayers' suits on the municipal level, see note 7 stpra) ; New Jersey; Vermont; Virginia; West Virginia.

In response to Yale Law Journal questionnaires, however, see note 47 infra, the office of the attorney general of the states of Maine, New Jersey, and Vermont indieated some experience with taxpayers' suits.

(2) Court specifically declined to rule on taxpayers' stasding: Standard Printing Co. v. Miller, 304 Ky. 49, 51, 199 S.W.2d 731, 732 (1946) ("Conceding, without deciding, that a taxpayer has the right to maintain this character of proceeding. ...."); Higgins v. Green, 56 R.I. 330, 335, 185 Atl. 686, 688 (1936) ("We will not express any opinion on this point ....").

(3) Latest decision obscures the law: Compare Aiken v. Armistead, $186 \mathrm{Ga}$. $36 \mathrm{~S}$, 387, 198 S.E. 237, 248 (1938) ("While . . . the writer would be inclined to the view 
century has been toward allowing such actions, however; courts which formerly denied state taxpayers standing have reversed themselves in recent years, ${ }^{34}$ while those courts considering the problem for the first time have been favorable to taxpayers' suits. ${ }^{35}$

This trend reflects the absence of significant reasons for distinguishing municipal taxpayers' suits, permitted practically everywhere, ${ }^{30}$ from their state counterparts. ${ }^{37}$ True, the taxpayer's contribution to the state treasury may be a lesser percentage of the total than his municipal tax payments, and his interest in state affairs might therefore be said to be more remote. But no overriding considerations-such as the need for executive flexibility on the national level in foreign affairs and defense ${ }^{38}$-make review of state action less desirable than review of the affairs of local government.

The underlying reasons for making payment of taxes the basis for standing to challenge governmental action have been obscured by judicial language designed to legitimize taxpayers' suits and to place restrictions upon the usc of this form of litigation. Although providing a convenient argument in

that a citizen and taxpayer is not without remedy in equity for a waste or unlawful expenditure of state funds ... it is the view of the entire court ... that a decision upon these questions is not required in the present case. . . . Should that occasion cver arise, it will be interesting to consider again the bearing of the following decisions by this court [citing Georgia cases allowing taxpayers' suits on the municipal level]."), with Ramsey v. Hamilton, 181 Ga. 365, 182 S.E. 392 (1935) (taxpayer has no standing to challenge state appropriations). See De Neffe v. Duby, 115 Ore. 511, 514, 239 Pac. 109,110 (1925) (failure of plaintiff to demonstrate special injury sufficient justification for dismissing his complaint, but "owing to the public importance of the authority of the Highway Commission...., we deem it advisable to" pass on the merits; challenged action upheid).

(4) Only early case which is unclear, and/or which may not be binding preccdent, found: Livermore v. Waite, 102 Cal. 113, 36 Pac. 424 (1894) (suit allowed; no discussion of standing issue); Martin v. Ingham, $38 \mathrm{Kan} .641,17 \mathrm{Pac} .162$ (1888) (taxpayer action against Governor not permitted, apparently because injunction or mandamus not forthcoming, since plaintiff did not pursue other remedies-making Governor aware of alleged irregularities so that he may commence statutory investigation). See also Letter From Office of the California Attorney General to the Yale Law Journal, Sept. 30, 1959, on file in Yale Law Library ("In California, the justiciable interest of a State taxpayer, as distinguished from a county or city taxpayer, in State treasury money has never been definitively established.").

34. See Reiter v. Wallgren, 28 Wash. $2 d$ 872, 184 P.2d 571 (1947) (dictum) (allowing standing); Borden v. Louisiana State Bd. of Educ., 168 La. 1006, 123 So. 655 (1929) (allowing standing). In 1937, the Massachusetts legislature changed the common law by passing a statute permitting taxpayers to enjoin state level expenditures. Miss. AnN. Laws ch. 29, § 63 (1952); see Richards v. Treasurer, 319 Mass. 672,67 N.E.2d 583 (1946). See generally Davis, supra note 32, at 388-89; Note, 50 HARv. L. REv. 1276, $1278-79 \&$ n.13 (1937).

35. See Davis, supra note 32 , at 388 n.127 (collecting cases); note 31 supra.

36. See note 7 supra.

37 See Turnipseed v. Blan, 226 Ala. 549, 148 So. 116 (1933); Fergus v. Russel, 270 III. 304, 315, 110 N.E. 130,135 (1915); Note, 50 HARv. L. REv. 1276, 1278 (1937).

38. See text at note 131 infra. 
favor of taxpayers' suits, the analogy to stockholder suits is imperfect ;9 the interests of a "municipal corporation's" taxpayers are different from those of stockholders in a private corporation. ${ }^{40}$ Thus, the stockholder's interest is based on wholly voluntary stock ownership, while the taxpayer's interest arises more or less compulsorily from residence within a municipality's territorial limits. Nor are the functions of a city, which may affect many aspects of a taxpayer's life and give rise to a great variety and volume of litigation, comparable to those of a corporation, which touch a stockholder's pocketbook only. The private corporation analogy is even less apposite when applied to taxpayers' actions brought against state officials, 11 since there qualification as a taxpayer involves a lesser degree of volition and governmental functions are more disparate from those of a corporation than in cases attacking the action of a municipality.

Further, the requirement that a plaintiff have an interest as contributor to the public treasury does not fully furnish the basis for his being granted standing to sue. Sometimes taxpayers have been granted standing to sue even when no apparent expenditure of governmental funds is involved. ${ }^{42}$. And even should a taxpayer-plaintiff allege waste of public moneys, any sum expended may have been spent whether or not the challenged action took place or may be infinitesimal in relation to total expenditures or tax revenues. ${ }^{\text {t3 }}$ Similarly, the taxpayer is not granted standing as some courts have asserted, principally to obviate future increases in tax burdens; the outcome of the suit may have no appreciable impact upon present or future levels of taxation.

39. See note 23 supra and accompanying text.

40. See Note, 50 Harv. L. Rev. 1276, 1276-77 (1937).

41. See id. at $1278 \&$ n.12.

42. N.Y. ALOO. BEv. CONTROL LaW \& 123 (taxpayer may enjoin illegal or unlieensed manufacture of wine, beer, or liquor); N.Y. Afult. Dwen. LAw \$ 355 (taspayer can sue, if appropriate municipal department does not, to enjoin prostitution in multiple dwelling units); Howard v. City of Boulder, 132 Colo. 401, 290 P.2d 237 (1955) (compel method of electing city councilmen).

43. For example, in Baim v. Fleck, 406 Ill. 193, 92 N.E.2d 770 (1950), a successful taxpayer's suit, apparently brought under III. REv. STAT. ch. 102, § 11 (1957), which provides that " $a$ suit in equity to restrain and enjoin the disbursement of public funds by an officer ... of the State government may be maintained ... by ... any ... tax payer of the state," prevented any disbursement of public funds for enforcement of a state statute preventing the serving of whiskey in glasses "deceptive in appearance" or "misleading as to capacity." Surely any expenditure here, if to be done at no extra expense by the policeman on his beat, is minimal in relation to a city or state budget. Accord, Gibson v. Board of Supervisors, 80 Cal. 359, 22 Pac. 225 (1889) (suit to compel election officials to recognize vote for bond issue); Ellingham v. Dye, 178 Ind. 336, 414, 99 N.E. 1, 29 (1912) ("The small proportionate sum of the cost of the election which would fall upon appellee as taxpayer is not of itself sufficient to destroy his competency to sue"); Altschul v. Ludwig, 216 N.Y. 459, 111 N.E. 216 (1916) (to enjoin issuance of permit for alteration of "firetrap" theatre).

44. See, e.g., Thomson v. City of Dearborn, 347 Mich. 365, 371, 79 N.W.2d 841, 844 (1956); Fergus v. Russel, 270 Ill. 304, 314, 110 N.E. 130, 135 (1915). 
The ultimate basis for granting standing to taxpayers must therefore be sought outside the normal language of the courts. Taxpayers' litigation seems designed to enable a large body of the citizenry to challenge governmental action which would otherwise go unchallenged in the courts because of the standing requirement. Such litigation allows the courts, within the framework of traditional notions of "standing," to add to the controls over public officials inherent in the elective process the judicial scrutiny of the statutory and constitutional validity of their acts. Taxpayers' suits also extend the uniquely American concept of judicial review of legislative action ${ }^{45}$ by allowing minorities ineffective at the ballot box to invalidate statutes or ordinances on constitutional grounds. Because the motive of a plaintiff-taxpayer is viewed as irrelevant, ${ }^{46}$ taxpayers' suits afford a means of mobilizing the self-interest of individuals within the body politic to challenge legislative programs, prevent illegality, and avoid corruption. Taxpayers' suits thus create an army of potential private attorneys general acting on whatever private incentives may induce them to spend the time and money to bring a taxpayer's suit: personal economic gain, partisan political objectives, desire to attract personal publicity, or to delay unwanted public projects, or to prevent expenditures believed to be socially or economically unwise. ${ }^{47}$ And since group financing of such litigation is not infrequent, taxpayers' suits also mobilize various

45. See, e.g., Freidrich, Constitutional Government and Denocracy 222-36 (rev, ed. 1950). Judicial review of legislative and executive action is currently available in several other countries. Douglas, Legal Institutions in America, in LEGAL Instirutions TOday ANd Tomorrow 285-86 (Paulsen ed. 1959) (Australia, Burma, Canada, France, India, Pakistan, Turkey).

46. Mock v. City of Santa Rosa, 126 Cal. 330, 58 Pac. 826 (1899) ; Turkovitch v. Board of Trustees, 11 Ill. 2d 460, 143 N.E.2d 229 (1957); Stewart v. Stanley, 199 La. 146, 5 So. $2 \mathrm{~d} 531$ (1941).

47. In order to obtain additional information on taxpayers' suits, the Yale Lane Journal sent a questionnaire relevant to the taxpayer standing problem to approximately 150 city attorneys' and 48 state attorneys general's offices-those people considered most likely to deal with taxpayers' actions. Answers were received from 28 state officials and approximately 50 city officials. The returned questionnaires [hereinafter cited as Qucstionnaire(s) ] are on file in the Yale Law Library. The Law Journal wishes to thank these public officials for their time and cooperation.

The questionnaire's third interrogatory listed 8 possible motivating forces bchind taxpayers' suits, and asked the answering official to rank motivating categories in what he believed was the order of greatest occurrence. Although a checklist may suggest answers that respondents might not ordinarily think of, Blum \& Kalven, The Art of Opinion Research: A Lawyer's Appraisal of an Enrerging Science, 24 U. Crr. L. Rev. 1, 12 (1956), the composite rankings were as follows:

1. Benefit to one's particular industry or business.

2. General displeasure over any new community action or public expenditure.

3. Partisan political reasons, as, for example, solely to embarrass elected officials.

4. Publicity or a desire to attract attention.

5. By losing contractors, hoping to gain a future contract by having the old contract declared invalid.

6. Idealistic or solely for the general community welfare. 
voluntary associations seeking private political, economic, or social objectives to further law enforcement and prevention of corruption in government. ${ }^{45}$

This view of the reasons for taxpayers' suits is supported by the treatment which has been accorded the definition of a "taxpayer." According to the generally stated rule, any taxpayer whose tax payments exceed a de minimis level may bring a taxpayer's suit, ${ }^{19}$ although in a few jurisdictions this rule has been qualified by statutes requiring a minimum number of taxpayers to join as plaintiffs. ${ }^{50}$ In some jurisdictions, the courts might allow only property taxpayers to bring taxpayers' suits, ${ }^{61}$ but in most the de minimis requirement would probably be broadly construed to allow payers of various forms of excises and income taxes to bring taxpayers' suits. 52 In fact, however, the courts almost never discuss the question "what is a taxpayer." This may result from the ability of any person wishing to challenge governmental action and willing to finance a suit to find a nominal plaintiff-or plaintiffs, when state law so requires-who will meet whatever criteria of taxpaying which

7. By attorneys to collect fees or a percentage of money saved the state or municipality.

8. Others.

Only 6 of 36 public officials venturing an answer thought that taxpayer's motive "never" influenced a court in reaching a decision; 14 responded "rarely," 15 "sometimes," 1 "often," while 18 answered "don't know."

48. Of the 44 definite (i.e., "yes" or "no") answers to interrogatory number eight of the questionnaire, 22 indicated "professional" backing for taxpayers' suits, though few public officials named any specific groups.

49. E.g., Ryan v. City of Chicago, 369 Ill. 59, 63, 15 N.E.2d 708, 710 (1938) (dictum) ("Where the expense ... is too trifling to constitute an injury to a taxpayer, such expenditure does not offer a basis for an equitable proceeding.").

50. ME Rev. Stat. ANN. ch. 90-A, § 56 (Supp. 1959) (ten taxpayers to enjoin contract violating conflict-of-interest statute); MAss. ANN. LAws ch. 29, $\S 63$ (1952) (twenty-four taxpayers to enjoin state level appropriations); MAss. Axis. LAw's ch. $40, \S 53$ (1952) (ten taxpayers to enjoin municipal appropriations); of. N.Y. Afusic. LAw $\$ 4$ (affidavit of twenty-five freeholders compels summary investigation of village or town's financial affairs.).

51. Cf. N.Y. Munic. LAw $\S 51$ (\$1000 worth of assessed property needed for suit against municipal official).

52. Putman v. Murden, 97 Ind. App. 313, 319, 184 N.E. 796, 799 (1933); Regan v. Babcock, 188 Minn. 192, 247 N.W. 12 (1933) (payment of automobile license fee and state gasoline tax gives taxpayer standing to challenge collusive arrangement among bidders for highway construction contracts); Legal Department, Lincoln, Neb., Questionnaire (payment of $\$ 4.00$ wheel tax sufficient to enable taxpayer to sue).

Courts have permitted nonresident taxpayers to bring suit. E.g., White Eagle Oil \& Ref. Co. v. Gunderson, 48 S.D. 60S, 205 N.W. 614 (1925) (nonresident taspayer allowed to enjoin state levy and collection of tases to finance state entrance into gasoline business) ; Commonweaith v. Scott, 112 Ky. 252, 266, 65 S.W. 596, 599 (1904) ; Brockman v. City of Creston, 79 Iowa 587, 44 N.W. 822 (1890); see Comment, 2 Burralo L. REv. 140, 143 (1952) ("Although it appears that the great majority of taxpayers' suits have been instituted by residents of the municipality, the better view is that place of residence is immaterial; plaintiff's interest as a taxpayer is no less because he resides elsewhere."). 
the courts might establish. ${ }^{53}$ In practice, therefore, the word "taxpayer" has been defined in such a manner that any person with adequate resources or backing is able to use that form of suit. Thus, "taxpayers' suits" have functionally become "citizens' suits."

A taxpayer's suit is a representative class action in equity, brought on behalf of all taxpayers ${ }^{55}$ against officials of the governmental unit challenged. The decision binds all other taxpayers; the legality of the challenged action is henceforth settled in other taxpayers' suits. ${ }^{56} \mathrm{~A}$ right to intervene protects other taxpayers from collusive or unenthusiastic prosecution. ${ }^{67}$ Although taxpayers' suits have all the attributes of an action against the sovereign, the courts have held that taxpayers' suits are not barred by the doctrine of sovereign immunity. A successful taxpayer's suit will in practice prevent the sovereign, through any of its officers, from carrying out the challenged action. But taxpayers' suits usually name certain public officials as defendants, ${ }^{68}$ and the fact that the suit is against the officials rather than the government itself is held sufficient to defeat sovereign immunity defenses.50

If a legal remedy is deemed adequate, a taxpayer-plaintiff must pursue it, and in these situations, the adequacy of legal remedies wotld be a good defense to a taxpayer's suit, ${ }^{60}$ as is laches. ${ }^{61}$ Discovery of relevant govern-

53. The use of nominal plaintiffs would not seem to run afoul of barratry statutes. Comment, 69 Y ALE L.J. 168, 176 \& nn.42-48 (1959).

54. Despite the seeming availability of the nominal plaintiff's device, however, ptiblic officials responding to the questionnaire still seemed leery of permitting "citizen" suits. Public officials were asked if they would "ever suggest allowing any citizen, even if he is not a taxpayer, to challenge governmental action?" Question 11(b). Of the 49 officials responding to this interrogatory, 39 said "no."

55. See 3 Moore, Federat Practice $\int$ 23.13, at 3482 (2d ed. 1948); 18 McQuilliN $\S 52.02$, at 3 ; Comment, 2 Buffalo L. Rev. 140 (1952); Note, 50 Harv. L. REv. 1276, 1283 (1937).

56. See 18 McQunlix $\S 52.50$; cf. Price v. Sixth Dist. Agricultural Ass'n, 201 Cal. 502, 258 Pac. 387 (1927).

57. Dowsett v. City of East Moline, 8 Ill. 2d 560, 134 N.E.2d 793 (1956). Sce generally 18 McQuillis $\$ \S 52.10,52.42$ \& n.93.

58. When municipal corporations are sued, the local unit itself often is and sometimes must be made a party. See, e.g., Stack v. Borelli, 3 N.J. Super. 546, 66 A.2d 904 (L. 1949) (City of Hoboken an indispensable party in suit to enjoin funds to special counsel); 18 McQuilLIN § 52.43, at 112 .

59. See, e.g., White Eagle Oil \& Ref. Co. v. Gunderson, 48 S.D. 608, 205 N.W. 614 (1925). Contra, Jones v. Reed, 3 Wash. 57, 27 Pac. 1067 (1891). But such stuits are now allowed in Washington provided the state attorney-general, on request, has refused to prosecute. State ex rel. Lemon v. Langlie, 45 Wash. 2d 82, 273 P.2d 464 (1954); Reiter v. Wallgren, 28 Wash. 2d 872, 184 P.2d 571 (1947) (dictum).

60. E.g., Glueck Realty Co. v. City of St. Louis, 318 S.W.2d 206 (Mo. 1958) (plaintiff could not maintain an equitable action as a taxpayer where he would have an adequate remedy in condemnation proceedings); see 18 McQunLIN $\S 52.08$, at 23 . But dismissals for this reason are infrequent. 4 Dillon at $\S 1573$; Note, 50 HAkv. L. REv. 1276, 1282 (1937).

61. E.g., Schnell v. City of Rock Island, 232 Ill. 89, 83 N.E. 462 (1907) (portion of suit dismissed that attempted to enjoin payment of a municipal indebtedness created 
mental documents is normally allowed freely, ${ }^{02}$ probably because of the public nature of most governmental documents and potential public opposition to refusals to disclose.

Although the remedy sought in a taxpayer's suit is invariably equitable, the relief desired varies with the types of governmental action challenged. The most usual relief is the injunction. ${ }^{63}$ But once an illegal or unconstitutional act or omission has occurred, the taxpayer, as agent for the public treasury, may in most jurisdictions be awarded affirmative monetary relief under a theory of restitution. ${ }^{64}$ In practice, such relief is probably awarded only in suits challenging a public official for appropriating funds for his own rather than a public purpose. If funds were spent for a public purpose or, a project was completed, relief may be barred by laches, or by the sued official's defense that his actions were a valid exercise of authority." Finally, the taxpayer may seek affirmative remedies from third parties. He may pursue a claim which the appropriate officials have failed to enforce or to enforce diligently and thus recover sums owing to the public treasury. ${ }^{C B}$

\section{State and Municipal Taxpayers' Suits in State Courts}

\section{The Objectives of Taxpaycrs' Suits}

The objectives sought by plaintiff-taxpayers have varied widely. ${ }^{07}$ In recent years, the greatest number of taxpayers' suits have been brought to challenge the increasing state and local government exercises of the eminent domain power in connection with slum clearance, housing, highway, airport, and other public works projects. ${ }^{88}$ Taxpayers have challenged the condemnation's legality on the grounds that the condemned property will be devoted

illegally thirty-four years earlier); see 18 MCQuirurs $\$ 52.40$; Note, 50 HARv. L. REv. $1276,1282-83$ (1937).

62. See, e.g., People ex rel. Busby v. Smith, 342 IIl. App. 448, 96 N.E2d 830 (1951). For a statutory permit to inspect, see N.Y. MunNIC. LAw $\$ 51$.

63. E.g., Pressman v. D'Alesandro, 211 AId. 50, 125 A.2d 35 (1956); Wirin v. Parker, 48 Cal. 2d 890, 313 P.2d 844 (1957); see 4 DuLoN $\$ 1579$, at 2763; 4 id. $§ 1587$, at 2783; 18 MCQumLIN \$ 52.02, at 3; Note, $50 \mathrm{HARv}$. L. Rev. 1276, 1277 \& n.8 (1937).

64. E.g., Howard v. Ader, 314 Ky. 213, 234 S.W.2d 733 (1950); see 4 Drwos § 1588 , at 2785 .

65. For example, if the public official was acting within his discretionary powers, a taxpayer's suit would not lie. E.g., City of Pueblo v. Flanders, 122 Colo. 571, 581, 225 P.2d 832, 837 (1950); see McQuinun § 52.07, at 23.

66. E.g., Ex parte Hart, 190 S.C. 473, 2 S.E.2d 52 (1939) (taxpsyer can sue on county's cause of action to set aside county order awarding attorncys extra compensetion after county unjustifiably refused to act); see 18 IfcQumsns $\$ \S 52.02,52.17$; Note, 50 HART. L. REv. 1276, 1277 (1937).

67. Public officials responsible for defending taxpayers' suits were asked to check-off the twelve suggested categories in their order of greatest occurrence. See nate 48 supro; Questionnaire question 3.

68. E.g., Bleecker Luncheonette, Inc. v. Wagner, 141 N.Y.S.2d 293 (Sup. Ct.), affd, 286 App. Div. 828, 143 N.Y.S.2d 628 (1955). 
to a private rather than a public use. ${ }^{60}$ (When the owners of condemned property receive compensation which they consider adequate, the only challenge practically possible may be through a taxpayer's suit.) ${ }^{70}$ Next in relative importance are taxpayers' suits attacking the constitutionality of the various methods of bond financing which states and municipalities have employed to circumvent constitutional limitations on indebtedness. ${ }^{71}$ In some circumstances, taxpayers have also been able to invalidate financing on the grounds that statutory requirements have not been met-for example, that a required referendum was not properly completed or that the requisite vote of public officials was not obtained. ${ }^{72}$ It may be conjectured that lending institutions bring some of these suits in order to obtain declaratory judgments on the financing's validity before a loan is consummated. Equally common with attacks on the method of financing have been taxpayer challenges to awards of contracts for public projects. These challenges have proceeded on two grounds: that the award violates a statute requiring letting of contracts to the lowest available bidder, ${ }^{73}$ or that it violates a conflict of interest statute prohibiting the letting of contracts to any person allied with responsible public officials, even if no lower bidder is present. ${ }^{74}$ When these statutes are not enforced by the public prosecutor, only a taxpayer's suit could challenge the award since the successful bidder would not contest it and competing bidders would not have standing as such. ${ }^{75}$ Also common are challenges of the granting of franchises or licenses, constituting public approval of privately owned but publicly used facilities. Such suits may be grounded on the theory that competing or alternative grantees are more desirable, that the

69. E.g., Visina v. Freeman, 252 Minn. 177, 89 N.W.2d 635 (1958) (aid to St. Lawrence seaway challenged as aiding private shipping interests). See also City Attorney's Office, Milwaukee, Wis., Questionnaire ( 3 out of 20 assistants needed to handle taxpayers' actions challenging condemnation awards).

70. A possible alternative is action by a state official. E.g., People $e . x$ rel. Gutknecht v. Chicago, 3 Ill. 2d 539, 121 N.E.2d 791 (1954) (quo warranto action) .

71. See generally Morris, Evading Debt Limitations With Public Building Authorities: The Costly Subversion of State Constitutions, 68 YALE L.J. 234, 240-43 (1958) (describing constitutional debt restrictions and evasive devices).

72. E.g., Whiting Co. v. City of Burlington, 106 Vt. 446, 175 Atl. 35 (1934); see Office of the Corporation Counsel, New Haven, Conn., Questionnaire ("Authority of Board of Finance to authorize expenditure of funds not allocated or approved by Board of Aldermen.").

73. See, e.g., Ill. Rev. Stat. ch. 24 \& 84-76a (1957) (lowest "responsible" bidder); OkLa. Stat. Ann. tit. 61, § 36 (Supp. 1959) (same).

74. E.g., Fla. Stat. Ann. $\$ 839.07,839.10$ (1944); Ill. Const. art. IV, $\S 25$; Ill. Rev. Stat. ch. 102, § 3 (1957); Okla. Stat. AnN. tit. 61, § 26 (Supp. 1959).

75. See Perkins v. Lukens Steel Co., 310 U.S. 113 (1940) (absent statutory authorization bidder as bidder has no standing to sue); Note, 59 Colum. L. Rev. 953, 955 \& n.15 (1959) (collecting state cases); cf. Tennessee Elec. Power Co. v. TVA, 306 U.S. 118 (1939) (private electric companies have no standing, as competitors, to enjoin fecleral government entrance into electric power industry); Alabama Power Co. v. Ickes, 302 U.S. 464 (1937) (same). Contra, OkzA. Stat. ANr. tit. 61, § 40 (Supp. 1959) (unsuccessful bidder may bring suit as bidder). 
grant is injurious to the public interest, or that it violates conflict-of-interest statutes.76 The next most important objective of taxpayers' suits has been to withhold salary payments to civil servants who hold office in violation of statutory standards. ${ }^{7 \pi}$

Although less frequent than the foregoing, a number of other objectives may be sought by plaintiff taxpayers. Some states have allowed taxpayers to challenge sales or donations of the public domain, often parks and recreational areas, to private parties. ${ }^{78} \mathrm{~A}$ celebrated but numerically unimportant type of taxpayer's suit is that designed to achieve "civil liberties" objectives, such as prevention of expenditures for schools, recreational areas and other public facilities, which would violate such constitutional guarantees as separation of church and state. ${ }^{79}$ Other suits have been brought to prevent expenditures for illegal methods of law enforcement, ${ }^{80}$ or to reapportion election or judicial districts. ${ }^{81}$

\section{The Permissible Scope of Taxpayers' Suits}

It could be argued that taxpayers' suits are unnecessary and inappropriate even on the municipal and state levels. The delay occasioned by taxpayer actions, even those that are ultimately unsuccessful and ill-founded, may unduly obstruct the completion of public projects. ${ }^{82}$ Taxpayers' suits' potential for harassment may encourage governmental immobility and inhibit progressive community action, while a multiplicity of taxpayer litigation may add to court congestion and unduly burden city officials who must defend against

76. E.g., Blanshard v. City of New York, 262 N.Y. 5, 186 N.E. 29 (1933) ; Schrueder v. Bunks, 415 I11. 192, 113 N.E.2d 169 (1953).

77. N.Y. CIV. SERv. LAw \& 102 (1) specifically provides for such suits.

78. See, e.g., Aldrich v. City of New York, 208 Afisc, 930, 145 N.Y.S.2d 732 (Sup. Ct. 1955).

79. See, e.g., Everson v. Board of Educ, 330 U.S. 1 (1947) (bus transportation to a parochial school); Engel v. Vitale, 191 N.Y.S.2d 453 (Sup. Ct. 1959) (prayers in public school); N.Y. Times, Dec. 20, 1959, § 1, p. 3, col. 6 (city ed.) (Burlington, Vermont, taxpayer suing to enjoin use of public funds for Catholic school tuition). See also Adler v. Board of Educ, 342 U.S. 485 (1952) ; Board of Regents v. Updegraff, 205 Okla. 301, 237 P.2d 131 (1951), rej'd stb nom. Wieman v. Updegraff, 344 U.S. 183 (1952).

80. E.g., Wirin v. Parker, 48 Cal. 2d 890, 313 P.2d 844 (1957) (concealed microphones by city police); Wirin v. Horrall, 85 Cal. App. 2d 497, 193 P.2d 470 (Dist. Ct. App. 1948) (police blockades and indiscriminate searches of automobile occupants).

81. See, e.g., Kuhn v. Curran, 184 Misc. 788, 56 N.Y.S.2d 737 (Sup. Ct. IU44) (taxpayer not given standing to challenge the creation of a tenth judicial district in Nassau and Suffolk counties). However, when the plaintiff taxpayer later asked for a mandamus to require the Secretary of State to disregard the statute, rather than velking an outright declaration of unconstitutionality, he was accorded standing. See Kulin v. Curran, 183 Misc. 942, 53 N.Y.S.2d 30 (Sup. Ct.), rev'd on other grosmds, 224 X.Y. 207. 61 N.E.2d 513 (1945).

82. See, e.g., Law Department, Philadelphia, Pa., Questionnaire (industrial redeveloyment program delayed over a year due to taxpayer's suit); City Attorney's (Office, Milwaukee, Wis., Questionnaire (urban redevelopment program temporarily halted). 
such suits, thereby adding to outlays for courts and public legal staffs. ${ }^{83}$ Most important, taxpayers' suits may push the concept of judicial review of legislative and executive action too far. ${ }^{84}$ By calling upon the courts to sit in judgment of decisions taken by the political branches of government, when no one is sufficiently injured thereby to have standing as an individual, taxpayer litigation may undermine the independence and prestige of the judiciary, impairing its ability to perform more traditional judicial functions. ${ }^{85}$ Since the courts are not designed, as are the political branches, to harmonize divergent views within the community and take action in accordance with the broadest possible consensus, such review may exceed their proper function. ${ }^{80}$ Moreover, placing the courts in the role of a "super legislature" may encourage irresponsibility and lack of creativity on the part of the political branches because they will be aware that decisions taken by them are always subject to judicial reversal.

Nevertheless, municipal and state taxpayers' actions appear irretrievably imbedded in the judicial and political system, ${ }^{87}$ and the arguments for allowing them in some circumstances are persuasive. The need for taxpayers' suits arises from the absence of alternative means of correcting illegal practices of government officials which would otherwise be irreparable. One alternative to taxpayers' suits is, of course, the elective process itself, but the electorate may ignore corruption, illegality, or unconstitutionality which occurred early in the term or which is relatively less eye-catching than the overall record of those in power; elections present package alternatives, often only two in number, and the voters are disabled from expressing their views on each governmental act. ${ }^{88}$

Public prosecution, either civil or criminal, is theoretically available to remedy most of the evils attacked in taxpayer litigation, and the widespread enactment of low-bidder and conflict-of-interest statutes ${ }^{80}$ enhances the potency of public remedies in fields where taxpayers' suits have been common.

83. The fear of a multiplicity of litigation has been one of the most common criticisms levelled at taxpayers' actions. See, e.g., Doolittle v. Supervisors of Broome County, 18 N.Y. 155 (1858); Massachusetts [Frothingham] v. Mellon, 262 U.S. 447, 487 (1923).

84. See id. at 487-88; e.g., Milhau v. Sharp, 15 Barb. 193, 236 (N.Y. Sup. Ct. 1853) (dissenting opinion); Asplund v. Hannett, 31 N.M. 641, 249 Pac. 1074 (1926).

85. See McWhinney, Judicial Review in the English-Speaking World 178 (1956) (judicial activism may limit court's prestige).

86. See, e.g., Nebbia v. New York, 291 U.S. 502, 530-32 (1934); Jay Burns Baking Co. v. Bryan, 264 U.S. 504, 517, 533-34 (1924) (dissenting opinion of Brandeis, J.); Lochner v. New York, 198 U.S. 45, 74 (1905) (dissenting opinion of Holmes, J.); Kelly \& Harbison, The American Constitution 789 (1948).

87. Davis, Standing To Challenge Governmental Action, 30 MrNN. L. Rev. 353, 430 (1955).

88. Only 1 of 37 officials answering question 10 of the Questionnaire (alternatives), thought that periodic elections eliminated the need for taxpayers' actions; 13 thought elections lessened the need, while 23 of the 37 thought periodic elections had no appreciable effect upon the need for taxpayers' actions.

89. See notes 73-74 supra. 
But the availability of such litigation is insurance against the instances in which the responsible prosecutors, usually political officers, are themselves allied with the action challenged or are overly burdened to identify and rectify every unconstitutional or illegal practice. It may be preferable to allow individuals or groups, whose self-interests motivate them to scrutinize particular aspects of governmental action more carefully than the prosecutors, to finance ad hoc litigation-taxpayers' suits-than to appropriate public money to expand governmental legal staffs on a permanent basis. Tort suits and other litigation by parties with standing outside the context of taxpayers' suits present viable alternatives in some situations, ${ }^{80}$ but taxpayers' suits often offer the only avenue to legal challenge, particularly when, as often happens, those sufficiently affected to have standing are the beneficiaries of the illegality or corruption.

Although public exposure may effect much the same cure as public prosecution, mass media will probably devote little space to reporting local and state government affairs which are not sensational.91 And, although state and local governments have adopted special means of obviating illegality and corruption, most have been less than fully successful. The initiative, referendum, and recall have served the corrupt as well as the reformers."2 Requirements of public hearings or referenda, before certain kinds of public projects can be implemented, may deter but not prevent illegal acts. In addition, the possibility of obtaining advisory opinions ${ }^{83}$ may afford the public insufficient protection when such opinions can only be requested by elected officials. of

But the availability of alternatives in many situations, combined with the arguments against taxpayer challenges of governmental action, necessitates careful delimitation of the proper scope of taxpayer litigation in order to

90. Actions based on violations of low-bidder or conflict-of-interest statutes, outside the taxpayer context may be provided for in the statute, see OrLA. Srar. Axx. tit. 61, $\$ 40$ (1949), or on tort allegations of interference with "prospective advantage," see Highway Paving Co. v. Hausmann, 171 F. Supp. 768 (ED. Pa. 1959), 59 Coluss. L. REv. 953.

91. In response to interrogatory number 10 of the $Q$ uestionmaire, none of 40 responding officials thought a category "Public opinion as expressed by mass media such as newspapers, radio and television" eliminated the need for taxpayers' suits; 23 officials thought this lessened the need while 17 of the 40 thought public opinion had no appreciable effect on the need for taxpayers' actions.

92. See Hofstader, The Age of Reforar, 265-66 (1955). In response to question 10 of the Questionnaire, only 4 of 37 officials thought the "Initiative, referendum, and recall" eliminated the need for taxpayers' actions; 11 of the 37 thought they lessened the need, while 22 of the 37 thought these alternatives had no appreciable effect on the need for taxpayers' actions.

93. See Letter From Office of the Attorney General, N.H., to the Yale Law Journal, Oct. 13, 1959, on file in Yale Law Library. ("One reason for this [scarcity of taxpayers' suits] may lie in the liberality of our Constitution in authorizing the Iustices of the Supreme Court to advise the Iegislature in advance of enactment of the constitutionality of pending bills.").

94. E.g., N.H. CoNsT. pt. 2, art. 74 (each branch of legislature, governor, and council to get opinions of justices upon important questions of law and upon solemn occasions). 
prevent its abuse. The scope of taxpayer litigation will depend upon (1) legal restrictions on such suits, (2) pecuniary deterrents to the unsuccessful litigant, and (3) pecuniary incentives available to the successful litigant.

\section{Legal Restrictions on Taxpayers' Suits}

A minority of cases have held that a taxpayer need only allege that the challenged action was illegal and affected some interest of the taxpayer even though it did not result in a pecuniary loss to the fund created by taxation. ${ }^{0 B}$ Usually, however, a taxpayer may sue only if his objective is to prevent or repair a pecuniary loss to that fund, ${ }^{90}$ a rule which misconstrues the underlying reason for granting taxpayers standing; although taxpayers' stits prevent misappropriation of public funds, it has been pointed out that their true basis is much broader : ensuring that illegal action by public officials will be remedied. ${ }^{97}$ Hence, it is not surprising that the pecuniary loss requirement is not strictly applied. ${ }^{98}$

More rational means of limiting the scope of taxpayer litigation than the pecuniary loss requirement would be available to jurisdictions desiring to do so. The most restrictive potential curb on taxpayers' actions, short of prohibiting them entirely, would be allowing them only when specifically provided by statute or ordinance. Taxpayers' suits could then be provided for in those areas where the legislature deems private challenge particularly desirable. But such a restriction on taxpayers' suits might have the effect of prohibiting challenges to public acts when they are most needed. Alternatively, taxpayer litigation could perhaps be limited to suits challenging illegal acts of public officials in the discharge of executive and not legislative functions. Thus taxpayers' suits designed to overturn acts of legislative bodies-state statutes or municipal ordinances-would be prohibited, and the use of taxpayers' suits to appeal to the courts as super legislatures in derogation of the separation of powers doctrine would be minimized.

\section{Pecuniary Deterrents to Taxpayers' Suits}

An unsuccessful taxpayer generally may be assessed the government's costs in accordance with the established rules relating to costs. ${ }^{09}$ In order

95. See Shipley v. Smith, 45 N.M. 23, 107 P.2d 1050 (1940).

96. E.g., Fristad v. Sherman, 76 N.W.2d 903 (N.D. 1956) ; Bassett v. Desmond, 140 Conn. 426, 101 A.2d 294 (1953); McCarthy v. McAloon, 79 R.I. 55, 83 A.2d 75 (1951); see 18 McQuillin $\S 52.13$, at 34 \& n.38.

97. See text at notes $45-48$ supra.

98. E.g., Baim v. Fleck, 406 Ill. 193, 92 N.E.2d 770 (1950); Aichele v. Borough of Oakley, 1 N.J. Super. 621, 624, 64 A.2d 924, 925 (L. 1948).

99. E.g., Letter From Office of the Attorney General, Wyo., to the Yalc Late Journal, Sept. 22, 1959, on file in Yale Law Library ("Under the law as it presently is in Wyoming the only cost that can be recovered is that for filing fees, cost of service and such."); see 18 McQuiLLin $\S 52.51$, at 125 ("Application is made, in a taxpayer's suit of the established rules relating to costs ...."). 
to prevent suits brought for purposes of harassment and delay, assessing the government's costs to a losing taxpayer seems proper. And since the government's legal staff is maintained on a year-round basis, its attorney's fees are likely to be relatively slight and may be difficult to ascertain; therefore, it seems proper not to assess them to a losing taxpayer. ${ }^{100}$ Government assumption of such fees would not seem too high a price to pay in a state which favors allowing challenges of governmental action via taxpayers' suits, and, since the unsuccessful taxpayer will be burdened with his own attorney's fees and costs and the costs of the government, no additional deterrent tu harassment suits would seem necessary. But when a third party is also challenged-in a suit to void a contract between the government and a third party, for example-the losing party should be assessed the costs and, at the discretion of the court, reasonable attorney fees for the third party. Otherwise, a financially strong taxpayer may be able to employ a taxpayer's suit as a means of private vengeance.

On the other hand, assessing the losing taxpayer provable damages of either the government or third parties resulting from a delay entailed in the litigation would seem undesirable and impractical. ${ }^{101}$ Particularly in a period of rising prices, such damages could be too high to be reasonably recoverable from the taxpayer, and all taxpayers' suits except those brought by" 'judgment proof' plaintiffs, or in their name, would likely be eliminated.

To deter frivolous suits $a b$ initio, six states have enacted the requirement that the taxpayer in some circumstances post bond sufficient to cover assessable costs and fees. ${ }^{102}$ Such security would seem a desirable deterrent since the taxpayer would thus be required to evince his good faith beiore the gorernment or third parties could be engaged in costly litigation, delaying the challenged action. It would also obviate harassment suits brought in the name of "judgment proof" plaintiffs, insulating the true party in interest from assessments for costs or attorneys' fees. ${ }^{103}$ But in order to ensure that

100. Contra, Letter From Office of the Attorney General, Wyo., to the Yale Lot" Journal, Sept. 22, 1959, on file in Yale Law Library (governmental unit should recover more costs or attorney's fees).

101. But see Legal Department, City of Council Bluffs, Iowa, Questiomaire (city"s darnages should be reimbursable by losing taxpayer).

102. Artz. Rev. Stat. Ans. §§ 11-642, 35-213 (1956); Ars. Star. Axw. § 84-1613 (1949); Cal. Civ. Proc. Code ANn. § 5266; Ill. Rev. Stat. ch. 102, \$§ 14, 16 (1957); N.Y. Munic Law $\$ 51$ (1954); Onio Rev. Code ANN. \$§ 309.12-.13, 733.59 (Page 1954).

Interrogatory number 7 of the Questionnaire asked: "Are bond or security requirements sufficient to protect your state or municipality from obstructionist taxpayers" suits or from those suits brought expressly for purposes of delay?" Out of 48 answering officials, 10 said they had adequate security protection; 15 said some protection, but inadequate; while 23 said no security protection existed.

103. If the bond were too high, however, it could operate to prevent bona fide, but financially weak, taxpayers from suing. Cf. Balnantine, Corporations 374 (rev. ed. 1946) (criticizing New York statute requiring security in stochholder derivative suits as a "practical denial of the only civil remedy that ordinary shareholders have ..."). 
the ability of financially weak taxpayers to bring suit is not unduly impaired, it would seem desirable to give the court discretion to waive the requirement of a bond if "probable cause" exists to believe that an illegal action has occurred. ${ }^{104}$ Alternatively, bond could be required only on appeal from the trial court when the taxpayer is unsuccessful on that level. ${ }^{105}$

\section{Pecuniary Incentives to Taxpayers' Suits}

Since a taxpayer will not bring suit unless he hopes to derive benefit therefrom, recovery of litigation costs seems the only necessary pecuniary incentive to taxpayers' suits, even in a state which is anxious to encourage this form of litigation. Oklahoma, however, allows the successful plaintiff, who brings suit after the public prosecutor has refused to do so, to recover a percentage of the funds saved the public treasury. ${ }^{100}$ This provision would seem to go far beyond the pecuniary awards necessary to ensure that good faith taxpayers' actions are possible, and may encourage a proliferation of unnecessary litigation.

A successful taxpayer-plaintiff usually can recover costs-such as filing fees and service fees ${ }^{107}$ _but may not recover what is probably the greatest expense of bringing suit, his attorneys' fees. ${ }^{108}$ But a handful of states have by statute allowed a successful taxpayer to recover reasonable attorney's fees from the municipal or state government. ${ }^{109}$ This departure from the usual rule that attorney's fees are not reimbursable-a departure which also exists in stockholder derivative suits ${ }^{110}$ _provides a strong incentive for taxpayers' suits. Since the theory of taxpayer litigation is employment of private motivations for public benefit, it is not unreasonable for the public to pay for private litigation expenses when the litigation inures to the advantage of the public treasury. Furthermore, if taxpayers' actions are to be available to all taxpayers equally, and not only to those with sufficient funds to pay litigation expenses, allowance of attorney's fees would seem essential, Since the amount of such fees could be set by the court, the court can have wide discretion to reward those who have benefited the public generally without unnecessarily encouraging a multiplicity of taxpayers' suits brought primarily for the purposes of obtaining public subsidy of the legal profession or of immobilizing governmental action. On the other hand, a requirement that the court always

104. IlL. Rev. Stat. ch. 102, $\S \S 14,16$ (1957) (initial judicial screening to see if probable cause for suit; if no probable cause, bond required).

105. See Law Department, Philadelphia, Pa., Questionnaire.

106. Okla. Stat. Ann. tit. 62, \& 373 (1949).

107. See note 102 supra.

108. 18 McQuiLlin $\$ 52-51$, at 877 , 882. In some circumstances, however, when money is recovered into the common fund, a court of equity may give the plaintiff attorney's fees. See, e.g., Fox v. Lantrip, 169 Ky. 759, 766-67, 185 S.W. 136, 139 (1916).

109. Aruz. Rev. Stat. Ann. \$§ 11-642, 35-213 (1956); Ohio Rev. Cove Ann. \& 309.13 (Page 1953) ; S.D. CODE \& 33.1803-1 (Supp. 1952).

110. Ballantine, Corporations 368-69 (rev. ed. 1946). 
award reasonable attorney's fees may not give the courts sufficient power to deter "strike" suits. 111 It would therefore seem preferable to give the courts a broader discretion by allowing them to refuse attorney's fees if the public interest would so require on the facts of the particular litigation, including the motive of the plaintiff.

\section{Taxpayers' Suits in the Federal Courts}

\section{The Federal Taxpayer}

After having dodged the issue, ${ }^{112}$ the Supreme Court in 1923, in Massachusetts [Frothingham] $v$. Mellon, ${ }^{113}$ squarely held that federal taxpayers have no standing as such to bring suits challenging acts or omissions of federal officials, and this decision still stands. ${ }^{11}$ Miss Frothingham had alleged that a federal grant-in-aid program aimed at reducing maternal and infant mortality was unconstitutional and that expenditures under the program-aggregating a maximum of $1,500,000$ dollars annually ${ }^{110}$-would, by increasing her

111. See, e.g., Mirphy v. North Am. Light \& Power Co., 33 F. Supp. 567, 571 (S.D.N.Y. 1940) (allowance of attorney's fees leads to speculation in fees by the attorneys for complainants).

112. Wilson v. Shaw, 204 U.S. 24, 31 (1907) (taxpayer's suit to enjoin funds for Panama Canal on grounds that United States does not have clear title to the land):

For the courts to interfere and at the instance of a citizen, who does not disclose the amount of his interest ... would be an exercise of judicial power which, to say the least, is novel and extraordinary .... We do not stop to consider these and kindred objections [to the basis of jurisdiction]; yet, passing them in silence must not be taken as even an implied ruling against ... their sufficiency. We prefer to rest our decision on the general scope of the bill.

113. 262 U.S. 447 (1923).

114. Doremus v. Board of Educ, 342 U.S. 429 (1952) (dictum); United States v. Butler, 297 U.S. 1 (1936) (dictum); Williams v. Riley, 280 U.S. 78 (1929) (dictum); Laughlin v. Reynolds, 196 F.2d 863 (D.C. Cir. 1952) (taxpayer cannot prevent bar association from using space in United States Court House for library purposes); Elliot v. White, 23 F.2d 997 (D.C. Cir. 1928) (taxpayer cannot enjoin disbursements to chaplains of the Senate, House of Representatives, and armed forces); Wheless v. Mfellon, 10 F.2d 893 (D.C. Cir. 1926) (taxpayer cannot challenge payments to veterans); Gart v. Cole, 166 F. Supp. 129, 135 (S.D.N.Y. 1958) (taxpayer would not have standing to challenge a federal grant to Fordham University, a Roman Catholic institution). In one anomolous case, however, where federal expenditures were inseparably interwoven with local action, a taxpayer was granted standing to sue. Franklin Township v. Tugwell, 85 F.2d 208, 228 (D.C. Cir. 1936). The expenditures were there thought to be but a step in an unconstitutional program giving the complainant an "immediate practical interest" in the controversy. See Note, 50 HARv. L. Rev. 1276, 1280 (1937).

115. The Maternity Act, ch. 135, 42 Stat. 224 (1921), provided grants to states that cooperated with the plans of the federal government to reduce maternity and infant mortality and to protect the health of mothers and infants. Appropriations were to be made annually, $\$ 480,000$ for the first year and $\$ 240,000$ for the five subsequent years. An additional amount of $\$ 1,000,000$ was also authorized for each of the six years. A Board of Maternity and Infant Hygiene, was established to administer the act; payments were to be withheld from states that did not comply with the Maternity Act's provisions. 
burden of future federal taxes, constitute a taking of property without due process of law. The Court dismissed the contention on the grounds that the taxpayer's interest was so remote that her suit presented no justiciable case or controversy within the meaning of article III of the Constitution. The result of the action, as the Court viewed it, would not be to prevent injury to the taxpayer but to invoke the equity powers of the Court to overrule actions of the Congress, a purpose out of harmony with the doctrine of separation of powers among the three branches of Government. The Court distinguished taxpayers' suits on the municipal level ${ }^{116}$ because such suits are "based on the peculiar relation of the corporate taxpayer to the corporation," and because the interest of the federal taxpayer "is comparatively minute and indeterminable ..." while the effect upon future taxation is "remote, fluctuating, and uncertain ...."

The only exception which the Court has made to Mallon is the limited one set forth in 1935 in United States $v$. Butler. ${ }^{118}$ There the Court upset the Agricultural Adjustment Act ${ }^{119}$ of 1933 which, as a means of remedying the agricultural depression, sought to support farm prices partially with taxes imposed upon processors of farm products. Since the tax on processors was viewed as an "indispensable part in the plan of regulation," 120 processors who paid the tax were held to have standing to challenge the constitutionality of the act, ${ }^{121}$ and Mellon was distinguished..$^{122}$ Butler would therefore seem applicable only when the plaintiff pays taxes that are part of a regulatory scheme and when those taxes, instead of being funneled into the national treasury, are earmarked for expenditure in furtherance of that scheme. ${ }^{123}$ Since a taxing provision with a comparable link to a spending program is seldom if ever enacted today, ${ }^{124}$ the Butler exception to Mellon is of little

116. 262 U.S. at 486-87. The court had previously entertained actions by District of Columbia taxpayers which had challenged District expenditures. E.g., Bradficld v. Roberts, 175 U.S. 291 (1899).

117. 262 U.S. at 487.

118. 297 U.S. 1 (1936).

119. Ch. 25, 48 Stat. 31 (1933).

120. 297 U.S. at 59.

121. Id. at 57-61. Nor did Mr. Justice Stone's dissenting opinion, id. at 78, take issue with the court's treatment of the standing problem.

122. Id. at 57-58 ("That case [Mellon] might be an authority ... if we were here concerned merely with a suit by a taxpayer to restrain the expenditure of the public moneys ... . But here the respondents who are called upon to pay moneys as taxes, resist the exaction as a step in an unauthorized plan. This circumstance clcarly distinguishes the case.").

123. But see Note, 2 U.C.L.A.L. Rev. 129, 131 (1954), interpreting Cain v. United States, 211 F.2d 375 (5th Cir. 1954), as suggesting "that the rule of the Buller cise may no longer be recognized by the courts ...." As the tax involved in Cain was an income tax, and, as the court did not resolve the question as to whether the tax was earmarked-indeed, the fifth circuit's opinion did not even cite Butler-such a conclusion seems unwarranted.

124. See Comment, 34 Micr. L. Rev. 366, 373 (1936):

Accordingly, it must be regarded as a technical error in drafting the Agricultural 
consequence. For all practical purposes, therefore, the federal government and its officials are immune from challenge by way of taxpayers' suits. ${ }^{125}$

The Mellon decision has been criticized ${ }^{120}$ the Court's emphasis on the minuteness and remoteness of a federal taxpayer's interest is particularly dubious. The interest of many large corporate taxpayers may be neither remote nor minute under today's tax structure. ${ }^{127}$ And, although the Mfellon

Adjustment Act, that a tax and a system of benefit payments were incorporated in one law, thus enabling taxpayers to obtain an easy freehold from which to upset the entire act. If new . . measures are enacted by the present Congress ... the taxing provisions will doubtless be entirely separate.

125. Concerning challenges to federal expenditures, Mellon and Butler leave two questions unanswered. First, may Congress constitutionally pass a statute authorizing taxpayers to sue? In a measure introduced in Congress in 1949, the Barden Bill, H.R. 4643 , 81st Cong., 1st Sess., $\$ 51$ (1949), which passed the House but not the Senate, and would have granted federal aid for "current expenditures" for public and secondary schools, would have permitted taxpayers to sue to prevent unasthorized expenditures or to enforce compliance with the provisions of the act. See HART \& WecusLen, Tue Federai Courts and The Federal Systexs 166 (1953). Since Mellon was announced in constitutional terms, it would appear that such permissive grants to taxpayers are prohibited to Congress. Second, though a single taxpayer cannot suc, can the Attorney General, as representative of all taxpayers, bring an action to prohibit illegal expenditures? See Comment, 18 ILI L. Rev. 204, 205 (1924). In such a circumstance, the Attorney General, viewed as representing all the people, and hence all taxpayers, could be viewed as having such a large and ascertained interest in federal moneys as to give him standing to enjoin its illegal use.

126. See Davis, Standing To Challenge Gozernmendal Action, 39 Mfrx. L. Rex. 353, 386-91 (1955) ; Note, 24 Geo. L.J. 974 (1936) ; Note, 37 Hakv. L. REx. 750 (1924). For a unique explanation of the opinion in terms of the popularity of the Mfaternity Act and the political philosophy of the Court, see Finkelstein, Judicial Self-Limifation, 37 HARv. L. REv. 338, 359 (1924).

127. For the fiscal year 1958, total budget expenditures by the federal government were $\$ 71,896,545,201$. The World Alaranac 748 (1959). In fiscal 1957, such expenditures were $\$ 69,433,078,427$. Ibid. Some of the federal income tax payments made by several larger corporations during recent years were:

\begin{tabular}{|c|c|c|c|c|c|}
\hline $\begin{array}{l}\text { Calendar } \\
\text { year end- } \\
\text { ing Dec. } 31\end{array}$ & $\begin{array}{l}\text { General } \\
\text { Motors }\end{array}$ & $\begin{array}{l}\text { E.I. Dupont } \\
\text { de Nemours } \\
\text { \& Co. }\end{array}$ & $\begin{array}{l}\text { Unitcd States } \\
\text { Steel Corp. }\end{array}$ & $\begin{array}{c}\text { Standard Oil } \\
\text { of Neiu } \\
\text { Jersey }\end{array}$ & $\begin{array}{l}\text { American } \\
\text { Telephone } \\
\text { and Tele- } \\
\text { graph Co. }\end{array}$ \\
\hline 1958 & $\$ 362,782,669$ & $\$ 189,090,000$ & $\$ 285,000,000$ & $\$ 400,000,000$ & $\$ 914, \$ 97,000$ \\
\hline 1957 & $703,221,324$ & $272,120,000$ & $405,000,000$ & $404,000,000$ & $753,767,013$ \\
\hline 1956 & $804,949,128$ & $251,920,000$ & $331,000,000$ & $430,000,000$ & $695,226,893$ \\
\hline 1955 & $1,353,350,357 *$ & $313,000,000$ & $366,000,000$ & $414,000,000$ & $626,939,691$ \\
\hline 1954 & $747,049,068$ & $258,290,000$ & $190,000,000$ & $311,000,000$ & $508,905,696$ \\
\hline \multirow[t]{4}{*}{1953} & $803,561,513$ & $404,840,000$ & $270,000,000$ & $329,000,000$ & $459,087,303$ \\
\hline & $+192,090,275$ & & & & \\
\hline & excess profits & & & & \\
\hline & $\operatorname{tax}$ & & & & \\
\hline
\end{tabular}

*Figures include other taxes besides federal income taxes.

See 1959 Moody's Industrial Manual 2737, 1725, 2799, 1651; 1959 Mloody's Public UTILTTY MAANUAL 1345. If twenty or thirty of the country's larger corporations were 
Court attempted to distinguish municipal taxpayers' suits on grounds of the flimsy analogy to the stockholders' derivative suit, ${ }^{128}$ it made no attempt to distinguish taxpayers' suits on the state level, which may involve interests more remote and minute than those of the federal taxpayers. The California taxpayer, for example, may have no greater interest than plaintiff Frothingham had in 1923 or than, for example, A.T. \& T. has in 1960.

Nevertheless, sound grounds exist today, perhaps much more sound than when Mellon was handed down, for denying federal taxpayers standing to challenge federal action as taxpayers. First, whether or not state taxpayers whose interests may be more remote than some federal taxpayers, have standing in state courts is irrelevant to the question, since federal courts must make an independent determination of whether the federal constitutional requirement of "case or controversy" has been met. ${ }^{129}$ Second, of perhaps greater importance, the economy is permeated with expenditures emanating from the federal budget, which exceeds the aggregate of all state and local budgets, ${ }^{130}$ and the acts or omissions of federal officials have a far-reaching impact. If standing were granted any federal taxpayer to challenge these federal activities, a proliferation of litigation could be anticipated. Furthermore, because of the different nature of the bulk of the federal expenditures-roughly twothirds are devoted to the sensitive areas of defense and foreign affairs ${ }^{101}$ judicial review of federal action initiated in taxpayers' suits is particularly inappropriate. Such expenditures are now relatively free from judicial intervention because they do not normally give rise to individual injuries sufficient to warrant standing in federal courts. This absence of judicial review scems desirable in view of the greater need for legislative and executive discretion and flexibility in the fields of foreign affairs and defense, the institutional

to join as plaintiffs in the same suit, the argument against taxpayers' suits based on remoteness or minuteness would appear even more inapplicable. See also Davis, supra note 126 , at 387,430 .

128. Massachusetts [Frothingham] v. Mellon, 262 U.S. 447, 486-87 (1923).

129. One commentator has taken the view that because many state courts since Mellon have allowed taxpayers' suits, and that since the majority of states allow these suits, Mellon is undesirable. Davis supra note 126 , at 388,430 . The obvious answer is that states may have different constitutional requirements than the "case or controversy" requirement of the federal court.

130. Total state and local expenditures in 1958 and 1957 were approximately $\$ 52.6$ billion and $\$ 45.1$ billion. These figures are derived as follows. U.S. BUREAU of THL Census, Dep't of Comarerce, Statistical Abstract of the United States 303 (1959), lists total governmental expenditures for these years as $\$ 124.5$ billion and $\$ 114.5$ billion. Subtracting federal expenditures $-\$ 71.9$ billion and $\$ 69.5$ billion, The World AlManac 748 (1959) - gives the state and local expenditures.

131. Expenditures for "Mutual Security" and "Military Functions" amounted to $\$ 43,070,702,380$ out of a total budget of $\$ 71,896,545,201$ in fiscal 1958 , and to $\$ 43,189,643$,855 out of a total of $\$ 69,433,078,427$ in fiscal 1957. The World Alunanac 747 48 (1959). Moreover, other expenditures pertinent to defense or foreign affairs, such as the State Department and the Central Intelligence Agency, were not included in the Almanac's tabulation of "Mutual Security" and "Military Functions" expenditures. 
frailties of courts in reviewing executive and legislative action in these areas, and problems of discovery of necessary documentation and information.132 Finally, although state and local governments have found taxpayers' suits and other between-election means of reviewing official action essential to avoid unconstitutionality and illegality, such devices are arguably less important on the federal level. Washington is the political cynosure of the nation, and federal officials are more susceptible to the pressures of public exposure and criticism than are many local and state officials, whose activities may often be carried on in relative obscurity. ${ }^{133}$ And, official actions on the national level reflect upon the party in power throughout the country and therefore possess greater built-in protection against corruption and illegality.

\section{The State or Municipal Taxpayer in Federal Court}

\section{Original Jurisdiction}

A state or municipal taxpayer might attempt to initiate his suit in federal district court by invoking diversity jurisdiction, ${ }^{134}$ or, if he were challenging local action on federal constitutional or statutory grounds, federal question jurisdiction. ${ }^{135}$ When diversity is the sole ground for jurisdiction, it might be contended that since the federal court would be performing the functions of a state court, state standing requirements are within the rule of Eric R.R. v. Tompkins, ${ }^{136}$ and therefore that federal courts should look to state precedents on the dispute's justiciability, irrespective of federal concepts of "case or controversy." But since diversity cases constitute one field to which "the judicial power of the United States" extends, and since that judicial power is nonexistent, absent a "case or controversy" in the federal sense, ${ }^{137}$ a federal court may not look to state law for standing criteria, even in diversity cases. It of course follows that federal criteria of standing are the only ones applicable to federal question cases.

Even so, federal standing criteria would probably be met in most state and municipal taxpayers' suits. The Mellon Court distinguished suits by municipal taxpayers, whose interests it deemed less remote than those of federal taxpayers, and stated in dictum that such suits present a justiciable case or controversy. ${ }^{138}$ Although state taxpayers have a more remote interest and the Court in Mellon did not mention state taxpayers' suits, Mellon should

132. Cf. United States v. Reynolds, 345 U.S. 1 (1935); Republic of China v. National Union Fire Ins. Co., 142 F. Supp. 551 (D. 11d. 1956).

133. For an analysis of the extensive press coverage in Washington, see Cater, TaE Fourte Branch of Governarent (1959) ; Time, Feb. 15, 1960, p. 74, col. 3 ("There are more journalists (1361) in the nation's capital than there are Congressmen.").

134. 28 U.S.C. \& 1332 (1958).

135. 28 U.S.C. \& 1331 (1958).

136. 304 U.S. 64 (1938).

137. See U.S. CoNST. art. III, § 2.

138. Massachusetts [Frothingham] v. Mellon, 262 U.S. 447, 486-87 (1923). 
apply only to federal taxpayers' actions. ${ }^{130}$ Both state and municipal taxpayers' actions initiated in state courts have been found to meet the constitutional case or controversy requirement when taxpayers have invoked the appellate jurisdiction of the Supreme Court, ${ }^{140}$ and it would be inconsistent to deny that this requirement has been met in cases of orginal federal jurisdiction.

In any event, origination of taxpayers' suits in fecleral court has in practice been barred by the Supreme Court's treatment of the statutory jurisdictional requirement of a minimum amount in controversy. ${ }^{141}$ The plaintiff taxpayer, the Court has held, must establish that his tax contribution to the challenged action is at least the jurisdictional amount, and a showing that the total expenditure for the challenged action exceeds that figure is insufficient. ${ }^{142}$ Although one early Supreme Court case, Broum v. Trousdale, ${ }^{143}$ allowed a state taxpayer to compute the total loss to all taxpayers for the purpose of establishing the amount in controversy, ${ }^{144}$ and this result is in harmony with the usual practice in stockholder derivative suits in which the plaintiff is permitted to compute the sum affecting the entire class represented as the amount in controversy, ${ }^{145}$ all subsequent cases have taken the contrary view, sub silentio overruling Brown ${ }^{146}$ and effectively withdrawing original federal court cognizance from state and municipal taxpayers' suits.

139. Contra, Williams v. Riley, 280 U.S. 78 (1929) (6-3 decision) (state taxpaycr cannot challenge state gasoline tax in federal district court; relying on Mcllon); sec Morgan v. Graham, 17 Fed. Cas. 749 (No. 9801) (C.C.D. La. 1871) (Bradley, Circuit Justice) (state taxpayers' suits not allowable in diversity case on rationale that muttiplicity of litigation and harassment of public officers would follow).

Federal courts have not hestitated to permit taxpayers' suits challenging expenditures of territorial legislatures. Reynolds v. Wade, 249 F.2d 73 (9th Cir. 1957) (Alaskan taxpayer has standing to challenge statute providing public transportation to non-public schools) ; Buscaglia v. District Court, 145 F.2d 274 (1st Cir. 1944), cert. denicl, 323 U.S. 793 (1945) (Puerto Rican taxpayer has standing to enjoin allocation of funds for which no statutory authority exists). Both cases specifically distinguished Mellon.

140. See notes 148-64 infra and accompanying text.

141. The jurisdictional amount is currently $\$ 10,000$. 28 U.S.C. $\$ 1332$ (1958). Prior to 1958 , the jurisdictional amount for $\S 1331$ and $\S 1332$ actions had been $\$ 3,000$. See Act of July 25, 1958, 74 Stat. 415.

142. Scott v. Frazier, 253 U.S. 243 (1920); Rogers v. Hennepin County, 239 U.S. 621 (1916); Colvin v. Jacksonville, 158 U.S. 456 (1895).

143. 138 U.S. 389 (1891).

144. Id. at 396. But see Blume, Jurisdictional Amounts in Representative Suits, 15 MinN. L. REv. 501, 509 (1931) (amount of bonds and not interest of complainants at issue in Brozen).

145. 3 Moore, Federai Practice If 23.13, at 3481 (2d ed. 1948).

146. Colvin v. Jacksonville, 158 U.S. $456,460-61$ (1895), attempted to distinguish Brown. But since both cases involved diversity taxpayers attempting to enjoin a bond issue, the facts of the two cases appear indistinguishable. An attempt has been made to distinguish Brown on the grounds that the plaintiff was asserting a "public right" rather than a "personal right." 3 Moore, Federal Practice $\{$ 23.13, at 3483 (2d ed. 1948). It would not seem possible to make such a distinction since all taxpayers' actions involve an assertion of private rights in order to protect, as the plaintiff sees them, public rights. 
This departure from the normal procedure for calculating the amount in controversy in class actions, although not well-reasoned in the opinions, would seem supported by considerations of harmony within the federal system. State courts should perhaps be left to work out their own solutions to problems created by unconstitutionality, corruption, or illegality on the municipal and state levels since federal court review of such matters (when they do not sufficiently injure any person to provide standing outside the framework of a taxpayer's suit), might unduly stir up frictions between federal and state institutions. ${ }^{147}$ And, since nominal plaintiffs are common in taxpayers' suits, an aggrieved person could usually finance a taxpayer's suit brought in the name of an out-of-state taxpayer in order to take advantage of diversity jurisdiction. Hence, most state and local taxpayer litigation might drift to the federal courts because the aggrieved parties might anticipate a more neutral hearing in that forum.

\section{Appellate Jurisdiction}

When a state or municipality has accorded its taxpayers standing to challenge public action on federal constitutional grounds, uncertainty surrounds the ability of the taxpayer, unsuccessful in the highest state court, to invoke the appellate jurisdiction of the Supreme Court of the United States. In Doremis v. Board of Educ., ${ }^{148}$ the Court dismissed a taxpayer's appeal because it found no justiciable case or controversy. ${ }^{149}$ The taxpayer had sought to enjoin Bible reading in a public school as violative of the "establishment of religion" clause of the federal constitution. Although granted standing by the state court, ${ }^{150}$ which denied the injunction on the merits, the taxpayer was found

147. Indeed, under recent decisions, the federal district judge might often exercise discretion to remand issues in taxpayers' suits to the state courts, and denial of permission to originate such suits in federal courts may therefore be of less significance. See Louisiana Power \& Light Co. v. City of Thibodaux, 360 U.S. 25 (1959); Harrison v. NAACP, 360 U.S. 167 (1959) ; Chicago v. Fielderest Dairies, Inc, 316 U.S. 168 (1942); Railroad Comm'n v. Pullman Co., 312 U.S. 496 (1941); Note, 69 YALE L.J. 643 (1960).

148. 342 U.S. 429 (1952), 50 MICH. L. REv. 1100.

149. We do not undertake to say that a state court may not render an opinion on a federal constitutional question even under such circumstances that it can be regarded only as advisory. But, because our own jurisdiction is cast in terms of "case or controversy," we cannot accept as the basis for review, nor as the basis for conclusive disposition of an issue of federal law without revicw, any procedure which does not constitute such.

342 U.S. at 434.

150. Apparently the sole purpose and the only function of plaintiffs is that they shall assume the role of actors so that there may be a suit which will involse a court ruling upon the constitutionality of the statute. Respondents urge that under the circumstances the question is moot as to the plaintiffs-appellants and that our declaratory judgment statute may not properly be used in justification of such a proceeding. ... The point has substance but we have nevertheless concluded to dispose of the appeal on its merits.

5 N.J. $435,439,75$ A.2d 880, 882 (1950). 
by the Supreme Court not to have brought a "good faith pocketbook action" since Bible reading would cause no pecuniary loss to plaintiff as a taxpayer. ${ }^{161}$ Thus, Doremus, when read with earlier cases, such as Everson, which allowed state or municipal taxpayers to invoke the Court's appellate jurisdiction, stands for the proposition that a state or municipal taxpayer does not have a direct enough interest for his suit to constitute an article III case or controversy unless the activity challenged involves an expenditure of public funds which would not otherwise be made. ${ }^{152}$ (Public funds were expended in Doremus to maintain the public school system in which the challenged Bible reading took place.)

But apparently restricting the scope of Doremus are two cases decided during the same term. On the same day as Doremus, Adler v. Board of $E d u c .{ }^{153}$ silent on the issue of taxpayers' standing in spite of a dissent by Mr. Justice Frankfurter based principally on that issue, ${ }^{154}$ allowed two municipal taxpayers to join two parents and four teachers (who also claimed standing as taxpayers) ${ }^{\mathbf{1 5 5}}$ in challenging expenditures made in enforcing a state statute designed to eliminate subversive schoolteachers. Like the Bible rending in Doremus, the enforcement of this statute would require no new expenditures of any meaningful proportions. ${ }^{156}$ Similarly, in Wieman $v$. Updegraff ${ }^{157}$ a taxpayer sought to enjoin salary payments to professors who refused to take a state loyalty oath, and the Court, on appeal by the professors involved who had intervened below, decided the case on the merits with no mention of standing. Presumably, any faculty member whose salary would have been discontinued had plaintiff-taxpayer succeeded would have been replaced and no saving would have accrued to the public treasury. ${ }^{158}$ Admittedly, both these

151. 342 U.S. at 434.

152. See Everson v. Board of Educ., 330 U.S. 1 (1947) (taxpayer may challenge public expenditures for buses to parochial schools); Hawke v. Smith, 253 U.S. 221 (1920) (taxpayer and elector suing to prevent Ohio secretary of state from printing ballots for a referendum on amendments to the federal constitution); Crampton v. Zabriskic, 101 U.S. 601 (1880) (suit to enjoin illegal bond issue). But see Heim v. McCall, 239 U.S. 175 (1915) (taxpayer's suit challenging the hiring of noncitizens for public work projects in violation of a New York statute).

"It is true that this Court found a justiceable controversy in Everson . . . . But Everson showed a measurable appropriation or disbursement of school-district funds occasioned solely by the activities complained of. This complaint does not." 342 U.S. at 434 .

153. 342 U.S. 485 (1952).

154. Id. at 497.

155. Id. at 502 .

156. Id. at 501 ; see Hart \& Wechsler, The Federat Courts and tile Federal. System 161 (1953) ("Can the two cases be reconciled?"); Sttpreme Court, 1951 Tcrm, 66 HARv. L. Rev. 89, 119-21 (1952) (Adler makes Court seem arbitrary in deciding what is a "case or controversy").

157. 344 U.S. 183 (1952).

158. See Davis, Standing To Challenge Governmental Action, 39 MinN. L. Rev. 353,427 (1955). Furthermore, if salary is at all dependent on length of service, a saving would occur. 
cases may be distinguished by the arguments that the standing of the taxpayers in Adler was deemed irrelevant because of the presence in court of other plaintiffs with different kinds of interests and, perhaps more persuasively, that Wieman, by the time it reached the Court, was no longer a taxpayer's suit, but an appeal by professors about to be dismissed. Nonetheless, Adler and Wieman have been regarded in the literature as taxpayers' suits, ${ }^{103}$ and, with Doremus, make prediction of the Court's action in future state taxpayer appeals nearly impossible. ${ }^{160}$

Assuming, however, that the above reading of Doremus-no case or controversy unless challenged action requires an added expenditure-is a correct interpretation of present law, the benefits of the opinion seem outweighed. Doremns seems designed, as is, in part, the standing requirement itself, to close the Supreme Court's doors to plaintiffs who seek to have state statutes declared unconstitutional when the surrounding circumstances do not demand the exercise of that extraordinary judicial power. ${ }^{101}$ Hence, the Court could have required that the particular plaintiff involved be himself personally injured. Instead (and consistently with the tradition of taxpayers' suits), the Court grounded its decision on the absence of pecuniary injury to taxpayers generally.

But the presence or absence of a reduction of the treasury, which, but for the challenged action, would not have occurred, seems a haphazard standard against

159. E.g., HART \& WECHSLER, op. cit. supra note 156, at 162-63.

160. In Doremus, by refusing to hear the case, the Court allowed the New Jersey Court's adjudication on the merits to stand, thereby raising another problem: this course allows varying precedents on the same constitutional issues to stand in the several states. Arguably, nothing objectionable exists in this, but the fact that the very clause of the Constitution which makes state judges responsible to the federal constitution is the supremacy clause, U.S. Const. art. VI, suggests the desirability of uniformity. One solution is that advocated by Professors Paul Freund and Willard Hurst:

FREUND: . . I I think it is a needed change to make standing to raise a federal constitutional question, itself a federal question, so that it will be decided uniformly throughout the country. I disagree with the Doremus case in so far as it lets the state judgment stand and merely declines review. It seems to me the Court should have gone the full way, holding that standing to raise a constitutional question is itself a federal question, that there was no standing and, therefore, the petition should stand dismissed in the state court and the decree vacated so that it would not be a precedent even in the state court.

HURST: . . I I agree with Mr. Freund. It seems to me these questions of litigable interest are constitutional issues. I agree with him that there should be a uniform doctrine on that.

Supreare Court and Suprexie Law 35 (Cahn ed. 1954). Query: When Professor Hurst expressed the feeling that standing is a conslitutional issue, was he agreeing with, or going beyond, the position of Professor Freund?

161. Even assuming, as I am, that a suspensive veto would be desirable, the power to annul a statute is much more than that. It does not send back the challenged measure for renewed deliberation; it forbids it by making a different appraisal of the values which . . . is the essence of legislation.

HAND, The BiLI of Righis 70 (1958) 
which to judge whether a taxpayer has a direct enough interest in the outcome of the litigation so that he would have standing for purposes of Supreme Court appellate jurisdiction. Notions of standing, in part, are designed to keep intact the institution integrity of the Court and to limit the Court's power to invalidate the actions of the other branches or of the states to those cases where the

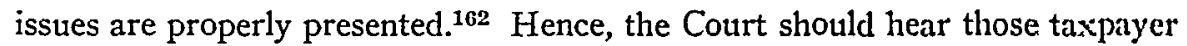
challenges of state action on federal constitutional grounds when, and only when, it is determined that a taxpayer is the most suitable private party 10 i to make the claim. Such a rule would ensure that federal constitutional law will not strike down state action prematurely, and, while perhaps unsatisfactory to those who would countenance constitutional invalidation of state action only when an individual is particularly injured, would provide, within the traditional framework of taxpayers' suits, a workable compromise between avoiding constitutional questions whenever at all possible and striking down unconstitutional action whenever requested so to do. ${ }^{104}$

162. See Joint Anti-Fascist Refugee Comm. v. MicGrath, 341 U.S. 123, 151 (concurring opinion of Frankfurter, J.).

163. While the public prosecutor would always seem to be a proper party, it does not seem practical to rely on public action. See notes $89-90$ supra and accompanying text.

164. The suggested test would achieve the same results as the Court in Everson (where taxpayers seem the only possible parties able to protest the expenditures for extra school buses) and in Doremus (where school children, or their parents, would seem to be more appropriate parties than taxpayers generally to protest Bible reading in schools). In Adler, the proposed test would deny standing to the two plaintiffs whose sole alleged interest was payment of taxes, since their coplaintiffs-teachers and parents-seem more appropriate parties to seek the invalidation of a state statute providing for the disqualification and removal of school teachers. 